Supporting Information for:

\title{
Generation of $\mathrm{a} \mathrm{Ni}_{3}$ Phosphinidene Cluster from the Ni(0) Synthon, $\mathrm{Ni}\left(\eta^{3}-\mathrm{CPh}_{3}\right)_{2}$
}

\author{
Alexander J. Touchton, Guang Wu, Trevor W. Hayton* \\ Department of Chemistry and Biochemistry, University of California, Santa Barbara, \\ California 93106, United States
}

*hayton@chem.ucsb.edu 


\section{Table of Contents}

Experimental Details

X-ray Crystallographic Data

NMR Spectra

S15

IR Spectrum

S33

Mass Spectra

S36

References

S39 


\section{Experimental Details}

All reactions and subsequent manipulations were performed under anaerobic and anhydrous conditions in the glovebox under an atmosphere of dinitrogen, unless otherwise noted. Diethyl ether $\left(\mathrm{Et}_{2} \mathrm{O}\right)$, toluene, and hexanes were dried by passage over activated molecular sieves using a Vacuum Atmospheres DRI-SOLV solvent purification system. Tetrahydrofuran (THF) was distilled twice, first from calcium hydride and then from sodium benzophenone ketyl, and stored over $3 \AA$ molecular sieves for $24 \mathrm{~h}$ prior to use. Pentane was dried on an MBraun solvent purification system and stored over activated $3 \AA$ molecular sieves for $24 \mathrm{~h}$ prior to use. Chloroform was sparged with $\mathrm{N}_{2}$ and dried over activated 3 Å molecular sieves for 24 h prior to use. Benzene- $d_{6}\left(\mathrm{C}_{6} \mathrm{D}_{6}\right)$, dichloromethane- $d_{2}\left(\mathrm{CD}_{2} \mathrm{Cl}_{2}\right)$, and toluene- $d_{8}$ were dried over activated $3 \AA$ molecular sieves for $24 \mathrm{~h}$ prior to use. $\mathrm{NiCl}_{2}$ was purchased from Strem and stirred in a mixture of diethyl ether/TMSCl for $18 \mathrm{~h}$ at room temperature prior to use. All other reagents were purchased from commercial suppliers and used as received.

All NMR spectra were collected at room temperature. ${ }^{1} \mathrm{H},{ }^{31} \mathrm{P}\left\{{ }^{1} \mathrm{H}\right\}$, and ${ }^{13} \mathrm{C}\left\{{ }^{1} \mathrm{H}\right\}$ NMR spectra were recorded on an Agilent Technologies 400-MR DD2 spectrometer, a Varian Unity Inova $500 \mathrm{MHz}$ spectrometer, or a Varian Unity Inova $600 \mathrm{MHz}$ spectrometer. ${ }^{1} \mathrm{H}$ and ${ }^{13} \mathrm{C}\left\{{ }^{1} \mathrm{H}\right\}$ NMR spectra were referenced to external $\mathrm{SiMe}_{4}$ using residual protio solvent resonances as internal standards. ${ }^{1}$ IR spectra were recorded on a Nicolet 6700 FT-IR spectrometer with a NXR FT Raman Module. Mass spectra were collected at the Materials Research Laboratory Shared Experimental Facilities at the University of California, Santa Barbara, using an electrospray ionization (ESI) 
source on positive ion mode with a Waters Xevo G2-XS TOF Time-of-Flight mass spectrometer. Elemental analyses were performed by the Micro-Mass Facility at the University of California, Berkeley.

Caution! Nickel tetra(carbonyl), $\mathrm{Ni}(\mathrm{CO})_{4}$, is highly toxic and highly volatile. It should only be handled in a glovebox or fumehood, and direct skin contact should be avoided.

Synthesis of $\mathrm{Ni}\left(\boldsymbol{\eta}_{3}-\mathrm{CPh}_{3}\right)_{2}$ (1). In a $20 \mathrm{~mL}$ scintillation vial equipped with a magnetic stir bar, triphenylmethane $(0.9423 \mathrm{~g}, 3.857 \mathrm{mmol})$ was dissolved in cold THF (12 mL, $\left.-25^{\circ} \mathrm{C}\right) .{ }^{n} \mathrm{BuLi}$ in hexanes $\left(2.5 \mathrm{M}, 1.54 \mathrm{~mL}, 3.85 \mathrm{mmol},-25^{\circ} \mathrm{C}\right)$ was then slowly added via syringe to the colorless, stirring $\mathrm{Ph}_{3} \mathrm{CH}$ solution, which resulted in a rapid color change to cherry-red. The solution was allowed to warm to room temperature. After stirring for $30 \mathrm{~min}$, the deep cherry-red solution was re-cooled to $-25{ }^{\circ} \mathrm{C}$ for $30 \mathrm{~min}$. After that time, the cold $\mathrm{Ph}_{3} \mathrm{CLi}$ solution was added dropwise to a cold, stirring suspension of $\mathrm{NiCl}_{2}(0.2499 \mathrm{~g}, 1.928 \mathrm{mmol})$ in cold $\mathrm{THF}\left(2 \mathrm{~mL},-25^{\circ} \mathrm{C}\right)$. The reaction mixture was allowed to warm to room temperature with stirring. After $1 \mathrm{~h}$, the cherryred color of the $\mathrm{Ph}_{3} \mathrm{CLi}$ solution was replaced by a deep purple color, concomitant with the deposition of a fine colorless solid and a microcrystalline purple solid. Removal of volatiles under vacuum provided an oily purple solid. The crude solid was triturated with pentane $(2 \times 1 \mathrm{~mL})$, removed from the glove box, and opened to air. The crude material was suspended in hexanes (HPLC grade, $20 \mathrm{~mL}$ ) and filtered through a medium porosity sintered glass frit, providing a colorless filtrate and leaving a mixture of purple and colorless solids on the frit. These solids were then rinsed with a 1:1 (v:v) acetonitrile (HPLC grade)/deionized water solution $(2 \times 20 \mathrm{~mL})$ and then neat acetonitrile (HPLC grade, $2 \times 10 \mathrm{~mL}$ ). The resulting fine purple powder was dried 
under vacuum for $3 \mathrm{~h}$ (0.4886 g, 46\% yield). Crystals suitable for X-ray crystallography were obtained from the vapor diffusion of pentane into a methylene chloride ( $2 \mathrm{~mL}$ ) solution of $\mathbf{1}(5 \mathrm{mg})$ stored at $-25^{\circ} \mathrm{C}$ for $72 \mathrm{~h}$. Anal. Calcd for $\mathrm{C}_{38} \mathrm{H}{ }_{30} \mathrm{Ni}$ : C, 83.69; $\mathrm{H}, 5.55$. Found: $\mathrm{C}, 83.75 ; \mathrm{H}, 4.09 .{ }^{1} \mathrm{H}$ NMR $\left(500 \mathrm{MHz}, 25{ }^{\circ} \mathrm{C}, \mathrm{CD}_{2} \mathrm{Cl}_{2}\right): \delta 6.10-$ $6.70(\mathrm{br}, o-\mathrm{Ph}, 8 \mathrm{H}), 6.60(\mathrm{br}, o-\mathrm{Ph}, 4 \mathrm{H}), 7.04(\mathrm{br} \mathrm{t}, p-\mathrm{Ph}, 6 \mathrm{H}), 7.11(\mathrm{br}, m-\mathrm{Ph}, 12 \mathrm{H}) .{ }^{1} \mathrm{H}$ NMR (500 MHz, $0{ }^{\circ} \mathrm{C}, \mathrm{CD}_{2} \mathrm{Cl}_{2}$ ): $\delta 6.29$ (br, o-Ph, 4H), 6.62 (br, o-Ph, 8H), 7.05 (br, m-Ph, 12H), 7.22 (br, p-Ph). ${ }^{1} \mathrm{H}$ NMR $\left(500 \mathrm{MHz},-20{ }^{\circ} \mathrm{C}, \mathrm{CD}_{2} \mathrm{Cl}_{2}\right): \delta 6.26(\mathrm{~d}, \mathrm{o}-\mathrm{Ph}, 4 \mathrm{H}), 6.59(\mathrm{~d}$, o-Ph, 8H), 6.97-7.09 (m, m-Ph, 12H), 7.23 (m, p-Ph, 6H). ${ }^{1} \mathrm{H}$ NMR $\left(500 \mathrm{MHz},-40{ }^{\circ} \mathrm{C}\right.$, $\left.\mathrm{CD}_{2} \mathrm{Cl}_{2}\right): \delta 6.25(\mathrm{~d}, o-\mathrm{Ph}, 4 \mathrm{H}), 6.57(\mathrm{~d}, o-\mathrm{Ph}, 8 \mathrm{H}), 6.99(\mathrm{t}, p-\mathrm{Ph}, 2 \mathrm{H}), 7.02-7.09$ (overlapping m, $m$-Ph, $12 \mathrm{H}$ ), $7.23(\mathrm{t}, p-\mathrm{Ph}, 4 \mathrm{H}) .{ }^{1} \mathrm{H}$ NMR $\left(500 \mathrm{MHz},-79{ }^{\circ} \mathrm{C}, \mathrm{CD}_{2} \mathrm{Cl}_{2}\right.$ ): $\delta$ $6.21(\mathrm{~d}, \mathrm{o}-\mathrm{Ph}, 4 \mathrm{H}), 6.53(\mathrm{br}, \mathrm{o}-\mathrm{Ph}, 8 \mathrm{H}), 6.98(\mathrm{t}, \mathrm{p}-\mathrm{Ph}, 2 \mathrm{H}), 7.04(\mathrm{~m}, \mathrm{~m}-\mathrm{Ph}, 12 \mathrm{H}), 7.23(\mathrm{t}$, p-Ph, $4 \mathrm{H}) .{ }^{13} \mathrm{C}\left\{{ }^{1} \mathrm{H}\right\}$ NMR $\left(126 \mathrm{MHz},-40{ }^{\circ} \mathrm{C}, \mathrm{CD}_{2} \mathrm{Cl}_{2}\right): \delta 144.27\left(\mathrm{CPh}_{3}\right), 134.52(\mathrm{o}-\mathrm{Ph})$, 130.47 (o-Ph), 128.35 (m-Ph), 125.80 (p-Ph), 125.13 (p-Ph). The ipso carbon resonances and one meta carbon resonance could not be located. IR ( $\mathrm{KBr}$ pellet, $\mathrm{cm}^{-}$ 1): 3053 (w), $1592(\mathrm{~m}), 1524(\mathrm{~m}), 1488(\mathrm{~m}), 1463(\mathrm{~m}), 1444(\mathrm{~m}), 1273(\mathrm{w}), 1145(\mathrm{~m})$, $1070(\mathrm{~m}), 1032(\mathrm{~m}), 900(\mathrm{vw}), 888(\mathrm{vw}), 872(\mathrm{vw}), 844(\mathrm{vw}), 811(\mathrm{vw}), 773(\mathrm{~s}), 758$ (s), $698(\mathrm{~s}), 689(\mathrm{~s}), 630(\mathrm{~m}), 613(\mathrm{~m}), 597(\mathrm{~m}), 504(\mathrm{w}), 470(\mathrm{w})$.

Synthesis of $\mathrm{Ni}\left(\mathrm{PPh}_{3}\right)_{4}$ (2). A $20 \mathrm{~mL}$ scintillation vial was charged with a magnetic stir bar, complex 1 (46.1 mg, $0.085 \mathrm{mmol}$ ), PPh3 (91 mg, $0.35 \mathrm{mmol}$ ), and toluene (20 $\mathrm{mL}$ ). The purple suspension was stirred for $48 \mathrm{~h}$ at room temperature, whereupon a clear orange-red solution had formed, concomitant with the dissolution of the purple solid. This solution was filtered through a Celite column supported on glass wool ( 0.5 $\mathrm{cm} \times 5 \mathrm{~cm}$ ). The filtrate was collected in a $20 \mathrm{~mL}$ scintillation vial, concentrated to 2 
$\mathrm{mL}$, and stored at $-25{ }^{\circ} \mathrm{C}$ overnight, resulting in the deposition of a brown microcrystalline solid. The pale brown supernatant was discarded and the solid was re-dissolved in toluene $(2 \mathrm{~mL})$ and layered with pentane $(18 \mathrm{~mL})$. Storage of this solution at $-25{ }^{\circ} \mathrm{C}$ for $24 \mathrm{~h}$ resulted in the deposition of 2 (70.2 $\mathrm{mg}, 70 \%$ yield) as a brown crystalline solid. ${ }^{1} \mathrm{H}$ NMR $\left(400 \mathrm{MHz}, 25{ }^{\circ} \mathrm{C}, \mathrm{C}_{6} \mathrm{D}_{6}\right)$ : $\delta 6.95$ (br s, overlapping $p$ $\mathrm{Ph}$ and $m$-Ph, 36H), 7.44 (br s, $m$-Ph, 24H). ${ }^{31} \mathrm{P}\left\{{ }^{1} \mathrm{H}\right\}$ NMR (162 MHz, $\left.25{ }^{\circ} \mathrm{C}, \mathrm{C}_{6} \mathrm{D}_{6}\right): 18.4$ (br s). These data match those previously reported for $2 .^{2}$

Reaction of 1 with CO. A $20 \mathrm{~mL}$ scintillation vial was charged with $\mathrm{Ni}\left(\eta^{3}-\mathrm{CPh}_{3}\right)_{2}$ (1) (1.7 mg, $0.0031 \mathrm{mmol}), \mathrm{CD}_{2} \mathrm{Cl}_{2}(1.5 \mathrm{~mL})$, and hexamethylbenzene (2.8 $\mathrm{mg}, 0.0173$ mmol). The resulting purple solution was filtered through a Celite column supported on glass wool $(0.5 \mathrm{~cm} \times 5 \mathrm{~cm})$ and transferred to a J. Young NMR tube. The tube was removed from the glovebox and the headspace was evacuated and replaced with CO (1 atm). The solution quickly turned from purple to colorless. After $10 \mathrm{~min}, \mathrm{a}{ }^{1} \mathrm{H}$ NMR spectrum was recorded, and after $10 \mathrm{~h}, \mathrm{a}^{13} \mathrm{C}\left\{{ }^{1} \mathrm{H}\right\}$ NMR spectrum was recorded. Then after $24 \mathrm{~h}$, the solution was decanted into a solution-phase IR cell and a IR spectrum was recorded. ${ }^{1} \mathrm{H}$ NMR $\left(500 \mathrm{MHz}, 25{ }^{\circ} \mathrm{C}, \mathrm{CD}_{2} \mathrm{Cl}_{2}\right): \delta$ 7.48-7.05 (overlapping $\mathrm{m}$, Gomberg's Dimer and $\mathrm{Ph}_{3} \mathrm{CH}$ aryl C-H), 6.94 (d, 4H, o-Ph, Gomberg's dimer), 6.21 (m, 2H, vinylic CH, Gomberg's dimer), 5.96 (m, 2H, vinylic CH, Gomberg's dimer), 5.55 (s, $\mathrm{Ph}_{3} \mathrm{CH}, 1 \mathrm{H}$ ), 5.12 (s, 1H, allylic $\mathrm{CH}$, Gomberg's dimer), 2.20 (s, $\left.\mathrm{C}_{6} \mathrm{Me}_{6}, 18 \mathrm{H}\right) .{ }^{13} \mathrm{C}$ NMR (101 MHz, $\left.\left.25^{\circ} \mathrm{C}, \mathrm{CD}_{2} \mathrm{Cl}_{2}\right): \delta 192.37(\mathrm{Ni}(C O))_{4}\right), 184.82$ (free CO), 144.55 (ipso C, $P h_{3} \mathrm{CH}$ ), 143.47, 142.25 (ipso Ph, Gomberg's dimer), 132.23 ( $C_{6} \mathrm{Me}_{6}$ ), 130.89 (o-Ph, vinylic phenyl, Gomberg's dimer), 130.61 (vinylic C, Gomberg's dimer), 129.90 (o-Ph, $P h_{3} \mathrm{CH}$ ), 129.68, 129.16 (vinylic C, Gomberg's dimer), 128.85 (m-Ph, $P h_{3} \mathrm{CH}$ ), 128.75, 128.44, 
128.39, 128.34 (Gomberg's dimer), 127.98, 127.88, 127.77, 127.68, 127.36 (Gomberg's dimer), 126.85 (p-Ph, $\mathrm{Ph}_{3} \mathrm{CH}$ ), 126.40 (Gomberg's dimer), 57.39 ( $\mathrm{Ph}_{3} \mathrm{CH}$ ), 44.11 (allylic C, Gomberg's dimer), 17.07 ( $\left.\mathrm{C}_{6} \mathrm{Me}_{6}\right)$ IR $\left(\mathrm{CD}_{2} \mathrm{Cl}_{2}, \mathrm{~cm}^{-1}\right): 2040$ (s). These data match those previously reported for $\mathrm{CO}$ dissolved in $\mathrm{CD}_{2} \mathrm{Cl}_{2},{ }^{3} \mathrm{Ni}(\mathrm{CO})_{4}{ }^{4}$ and Gomberg's dimer. ${ }^{5}$ Resonances without specific assignments remain unassigned.

In situ synthesis of 2. A $20 \mathrm{~mL}$ scintillation vial was charged with $\mathbf{1}(10.5 \mathrm{mg}, 0.0192$ mmol), $\mathrm{PPh}_{3}(20.2 \mathrm{mg}, 0.0770 \mathrm{mmol})$, and toluene- $\mathrm{d}_{8}(2 \mathrm{~mL})$ to provide a purple suspension. The vial was then equipped with a stir bar, and the reaction mixture was allowed to stir overnight. After $18 \mathrm{~h}$, the resulting deep red-orange solution was transferred to an NMR tube, and a ${ }^{1} \mathrm{H}$ NMR spectrum was recorded (see Figure S9).

Synthesis of $\left[\mathrm{Ni}_{3}\left(\mu_{3}-\mathrm{PPh}\right)\left(\mu-\mathrm{PPh}_{2}\right)_{2}\left(\mathrm{PPh}_{3}\right)_{3}\right]$ (3). A $50 \mathrm{~mL}$ Schlenk flask equipped with a Teflon rotoflow valve was charged with a stir bar, complex $\mathbf{1}(102.5 \mathrm{mg}, 0.1879$ mmol), $\mathrm{PPh}_{3}(99.3 \mathrm{mg}, 0.3801 \mathrm{mmol})$, and toluene $(10 \mathrm{~mL})$. The flask was sealed, removed from the glovebox, and placed in an oil bath heated to $75^{\circ} \mathrm{C}$. The deep purple suspension was then stirred for $15 \mathrm{~h}$. After $15 \mathrm{~h}$, the resulting deep brown solution was dried under vacuum, leaving an oily brown residue. This material was triturated with pentane $(4 \times 1 \mathrm{~mL})$, suspended in warm $\left(50^{\circ} \mathrm{C}\right)$ hexanes $(10 \mathrm{~mL})$, and filtered through a Celite column supported on glass wool $(0.5 \mathrm{~cm} \times 5 \mathrm{~cm})$. The yellow-brown filtrate was discarded, and the undissolved brown solids were dissolved in hot $\left(80^{\circ} \mathrm{C}\right)$ toluene $(10 \mathrm{~mL})$ and filtered through the same Celite column. The dark brown filtrate was then concentrated to $2 \mathrm{~mL}$ and layered with pentane $(15 \mathrm{~mL})$. Storage of this solution at $-25{ }^{\circ} \mathrm{C}$ for $48 \mathrm{~h}$ resulted in deposition of a brown solid (46.4 mg), which was isolated by decanting the supernatant. The brown solid was then re-dissolved in 
hot toluene $(10 \mathrm{~mL})$, filtered through a Celite column supported on a plug of glass wool $(0.5 \mathrm{~cm} \times 5 \mathrm{~cm})$, concentrated to $2 \mathrm{~mL}$, and transferred to a $4 \mathrm{~mL}$ glass vial. This vial was then placed inside a $20 \mathrm{~mL}$ scintillation vial. Hexanes $(2 \mathrm{~mL})$ was added to the outer vial, which was then sealed. Storage of this two-vial system at $-25^{\circ} \mathrm{C}$ for 2 weeks resulted in the deposition of brown plates of $3 \cdot 2 \mathrm{C}_{7} \mathrm{H}_{8}(39.0 \mathrm{mg}, 38 \%$ yield), which were isolated by decanting the supernatant. Anal. Calcd for $\mathrm{C}_{84} \mathrm{H}_{70} \mathrm{Ni}_{3} \mathrm{P}_{6}$ : C, 70.00; H, 4.90. Found: C, 70.04; H, 4.74. ${ }^{1} \mathrm{H}$ NMR $\left(600 \mathrm{MHz}, \mathrm{C}_{6} \mathrm{D}_{6}, 25{ }^{\circ} \mathrm{C}\right): \delta 7.80(\mathrm{~m}, \mathrm{o}-$ $\mathrm{Ph}, \mathrm{PPh}_{3}, 12 \mathrm{H}$ ), 7.70 (d, o-Ph, PPh, 2H), 7.45 (m, o-Ph, $\left.\mathrm{PPh}_{2}, 4 \mathrm{H}\right), 7.24$ (m, o-Ph, $\mathrm{PPh}_{2}$, 4H), 7.15-7.00 (br, o-Ph and m-Ph, $\mathrm{PPh}_{3}, 12 \mathrm{H}$ ), 6.97 (t, p-Ph, $\mathrm{PPh}_{3}, 8 \mathrm{H}$ overlapping with t, p-Ph, PPh, 1H), 6.91 (t, m-Ph, 12H, PPh $), 6.87$ (t, m-Ph, PPh, 2H), 6.82-6.79 (t, p-Ph, $\mathrm{PPh}_{2} 4 \mathrm{H}$ overlapping with $\left.\mathrm{p}-\mathrm{Ph}, \mathrm{PPh}_{3}, 3 \mathrm{H}\right), 6.64(\mathrm{t}, \mathrm{m}-\mathrm{Ph}, \mathrm{PPh}, 8 \mathrm{H}) .{ }^{1} \mathrm{H}\left\{{ }^{31} \mathrm{P}\right\} \mathrm{NMR}$ (400 MHz, $\mathrm{C}_{6} \mathrm{D}_{6}, 25^{\circ} \mathrm{C}$ ): $\delta 7.80$ (d, o-Ph, $\left.\mathrm{PPh}_{3}, 12 \mathrm{H}\right), 7.70(\mathrm{~d}, \mathrm{o}-\mathrm{Ph}, \mathrm{PPh}, 2 \mathrm{H}), 7.45(\mathrm{~m}$, o-Ph, PPh2, 4H), 7.24 (m, o-Ph, PPh2, 4H), 7.14-6.74 (m, overlapping Ph, 40H), 6.64 (t, m-Ph, $\left.\mathrm{PPh}_{2}, 8 \mathrm{H}\right) \cdot{ }^{13} \mathrm{C}\left\{{ }^{1} \mathrm{H}\right\}$ NMR (101 MHz, $\left.\mathrm{C}_{6} \mathrm{D}_{6}, 25^{\circ} \mathrm{C}\right) \delta 143.03$ (ipso Ph, $\left.\mathrm{PPh}_{2}\right), 141.15$ (ipso Ph, $\mathrm{PPh}_{2}$ ), 137.61 (ipso $\mathrm{Ph}, \mathrm{PPh}_{3}$ or PPh), 137.46 (ipso $\mathrm{Ph}, \mathrm{PPh}_{3}$ or $\mathrm{PPh}$ ), 137.09 (ipso Ph, $\mathrm{PPh}_{3}$ or $\mathrm{PPh}$ ), 135.81 (o-Ph, $\mathrm{PPh}$ ), 134.48 (o-Ph, $\mathrm{PPh}_{3}$ overlapping with o-Ph, PPh2), 134.34 (o-Ph, $\mathrm{PPh}_{3}$ ), 133.77 (o-Ph, $\mathrm{PPh}_{2}$ ), 129.15 (p-Ph, $\mathrm{PPh}_{3}$ ), 128.42 (m-Ph, PPh 3 ), 127.53 (p-Ph, $\mathrm{PPh}_{3}$ ), 127.44 (m-Ph, PPh), 127.36 (m-Ph, $\left.\mathrm{PPh}_{3}\right), 127.03$ (m-Ph, PPh2), 126.94 (m-Ph, PPh2), 126.78 (p-Ph, PPh), 126.38 (p-Ph, PPh2), 126.02 (p-Ph, $\left.\mathrm{PPh}_{2}\right) .{ }^{31} \mathrm{P}\left\{{ }^{1} \mathrm{H}\right\} \mathrm{NMR}\left(162 \mathrm{MHz}, 25{ }^{\circ} \mathrm{C}, \mathrm{C}_{6} \mathrm{D}_{6}\right) \delta 487.50\left(\mathrm{tt}, J_{\mathrm{PP}}=209.5, J_{\mathrm{PP}}=42.9 \mathrm{~Hz}, 1 \mathrm{P}\right)$, 122.37 (m, 2P), 41.67 (m, 2P), 34.05 (m, 1P). ESI-MS (THF, positive ion mode, $2 \mathrm{kV}$ ): m/z 1438.2681 [M+] (Calcd m/z 1438.1964). IR (KBr pellet, $\mathrm{cm}^{-1}$ ): 693 (vs), 730 (vs), 520 (s), 541 (s), 476 (s), $558(\mathrm{~m}), 1024(\mathrm{~m}), 1090(\mathrm{~m}), 445(\mathrm{~m}), 1121(\mathrm{~m}), 998(\mathrm{~m})$, 
$1042(\mathrm{~m}), 1159(\mathrm{~m}), 1434(\mathrm{~m}), 1069(\mathrm{~m}), 1476(\mathrm{~m}), 597(\mathrm{~m}), 618(\mathrm{~m}), 1581(\mathrm{~m}), 847$

(w), $1494(w), 1307(w), 3051(w), 1267(v w)$.

Spectroscopic monitoring of the reaction between 1 and PPh $_{3}$ : A $50 \mathrm{~mL}$ Schlenk flask equipped with a Teflon rotoflow valve was charged with a stir bar, complex $\mathbf{1}$ (40.0 mg, $0.073 \mathrm{mmol}$ ), $\mathrm{PPh}_{3}(37.4 \mathrm{mg}, 0.1425 \mathrm{mmol}$ ), and toluene (5 mL). The flask was sealed, removed from the glovebox, and placed in an oil bath heated to $75^{\circ} \mathrm{C}$. The deep purple suspension was then stirred for $15 \mathrm{~h}$. After $15 \mathrm{~h}$, the resulting deep brown solution was dried in vacuo, leaving an oily brown residue. This material was dissolved in benzene- $d_{6}(1.5 \mathrm{~mL})$, and the resulting deep brown solution was filtered through a Celite column supported on glass wool $(0.5 \mathrm{~cm} \times 5 \mathrm{~cm})$ and transferred to an NMR tube. ${ }^{1} \mathrm{H}$ and ${ }^{13} \mathrm{C}\left\{{ }^{1} \mathrm{H}\right\}$ NMR spectra were then recorded (Figures S14-S15). ${ }^{1} \mathrm{H}$ NMR (400 MHz, $\mathrm{C}_{6} \mathrm{D}_{6}$ ): $\delta 7.81$ (d, o-Ph, PPh $, 12 \mathrm{H}, 3$ ), 7.70 (d, o-Ph, PPh, 2H, 3), 7.46 (d, o-Ph, biphenyl), 7.40 (m, o-Ph, $\mathrm{PPh}_{2}, 4 \mathrm{H}, 3$ overlapping with o-Ph, free $\mathrm{PPh}_{3}$ ), 7.34 (m, unidentified product), 7.24 (m, o- $\mathrm{Ph}, \mathrm{PPh}_{2}, 3$ overlapping with biphenyl), 7.21 (t, $\mathrm{m}-\mathrm{Ph}$, biphenyl overlapping with 3), 7.16 (benzene), 7.13 (t, p-Ph, biphenyl overlapping with benzene), 7.08 (o- and p- $\mathrm{Ph}, \mathrm{Ph}_{3} \mathrm{CH}, \boldsymbol{A}$ ), 7.04 (m- and $\mathrm{p}-\mathrm{Ph}$, free $\mathrm{PPh}_{3}$ overlapping with $\mathrm{p}-\mathrm{Ph}, \mathrm{Ph}_{3} \mathrm{CH}, \mathrm{A}$, ), 6.97 (t, p-Ph, $\mathrm{PPh}_{3}$ overlapping with t, $\mathrm{p}-\mathrm{Ph}, \mathrm{PPh}$, 3), $6.91\left(\mathrm{t}, \mathrm{m}-\mathrm{Ph}, 12 \mathrm{H}, \mathrm{PPh}_{3}, 3\right), 6.80$ (t, $\mathrm{p}-\mathrm{Ph}, \mathrm{PPh}_{2} 4 \mathrm{H}$ overlapping with $\mathrm{p}-\mathrm{Ph}, \mathrm{PPh}_{3}, 3$ ), 6.73 (unidentified product), $6.64(\mathrm{t}, \mathrm{m}-\mathrm{Ph}, \mathrm{PPh} 2,8 \mathrm{H}, 3), 5.43\left(\mathrm{Ph}_{3} \mathrm{CH}, \mathrm{A}\right), 5.38$ (1- $(\mathrm{CH}$, diphenylmethyl)-4-(trityl)benzene, B) 3.82 (unidentified product), 3.78 (unidentified product), $2.11\left(\mathrm{CH}_{3} \mathrm{C}_{6} \mathrm{H}_{5}\right.$, toluene). ${ }^{13} \mathrm{C}\left\{{ }^{1} \mathrm{H}\right\} \mathrm{NMR}\left(25^{\circ} \mathrm{C}, 101 \mathrm{MHz}, \mathrm{C}_{6} \mathrm{D}_{6}\right) \delta 147.37$ (ipso $\mathrm{Ph}$, tentatively assigned to 1-(diphenylmethyl)-4-(trityl)benzene, B), 147.31 (ipso Ph, tentatively assigned to 1-(diphenylmethyl)-4-(trityl)benzene, B), 147.25, 147.16, 
145.35 (ipso Ph, tentatively assigned to 1-(diphenylmethyl)-4-(trityl)benzene, B), 144.42 (ipso $\mathrm{Ph}, \mathrm{Ph}_{3} \mathrm{CH}, \mathrm{A}$ ), 144.37 (ipso $\mathrm{Ph}$, tentatively assigned to 1(diphenylmethyl)-4-(trityl)benzene), 143.02 (ipso $\mathrm{Ph}, \mathrm{PPh} 2,3$ ), 142.03, 141.75 (ipso Ph, biphenyl), 141.02(ipso Ph, $\mathrm{PPh}$ 2, 3), 138.98, 138.07 (d, ipso $\mathrm{Ph}, \mathrm{PPh}_{3}$ ), 137.89 (ipso Ph, toluene), 137.65 (ipso $\mathrm{Ph}, \mathrm{PPh}_{3}$ or $\mathrm{PPh}, 3$ ), 137.46 (ipso $\mathrm{Ph}, \mathrm{PPh}_{3}$ or PPh, 3), 137.43, 137.09 (ipso $\mathrm{Ph}, \mathrm{PPh}_{3}$ or $\mathrm{PPh}, 3$ ), 135.83 (o-Ph, PPh, 3), 134.47 (o-Ph, $\mathrm{PPh}_{3}$ overlapping with o-Ph, $\left.\mathrm{PPh}_{2}, 3\right), 134.33$ (o- $\left.\mathrm{Ph}, \mathrm{PPh}_{3}, 3\right), 134.15$ (d, o- $\mathrm{Ph}, \mathrm{PPh}_{3}$ overlapping with o- $\left.\mathrm{Ph}, \mathrm{PPh}_{3}, 3\right), 133.74$ (o- $\left.\mathrm{Ph}, \mathrm{PPh}_{2}, 3\right), 131.66,131.61,131.57$, 130.88, 130.78, 130.24, 130.05, 129.92 (o-Ph, $\left.\mathrm{Ph}_{3} \mathrm{CH}\right), 129.89,129.71,129.33$ (o-Ph, toluene), 129.15 (p-Ph, $\mathrm{PPh}_{3}, 3$ ) , 129.06 (o-Ph, biphenyl), 129.02, 128.99, 128.88 (mor p-Ph, $\mathrm{PPh}_{3}$ ), 128.83 (m- or p-Ph, $\mathrm{PPh}_{3}$ ), 128.79 (m- or p-Ph, $\left.\mathrm{PPh}_{3}\right), 128.74,128.68$, 128.64, 128.62 (m-Ph, $\left.\mathrm{Ph}_{3} \mathrm{CH}, \mathrm{A}\right), 128.57$ (m-Ph, toluene), 128.47, 128.42 (m-Ph, $\mathrm{PPh}_{3}$, 3), 128.30, 128.18, 128.06, 127.98, 127.94, 127.90, 127.82, 127.71, 127.64, 127.54, 127.53 (p-Ph, $\mathrm{PPh}_{3}, 3$ overlapping with biphenyl), 127.51 (m-Ph, biphenyl overlapping with 3), 127.47 (p-Ph, biphenyl overlapping with 3), 127.44 (m-Ph, PPh, 3 overlapping with biphenyl), 127.36 (m-Ph, $\mathrm{PPh}_{3}, 3$ overlapping with biphenyl), 127.03 (m-Ph, PPh2, 3), 126.94 (m-Ph, PPh2, 3), 126.79 (p-Ph, PPh, 3), 126.56 (p-Ph, $\left.\mathrm{Ph}_{3} \mathrm{CH}, \mathrm{A}\right), 126.54,126.38$ (p-Ph, $\left.\mathrm{PPh}_{2}, 3\right), 126.25,126.21,126.17,126.03$ (p-Ph, $\mathrm{PPh}_{2}$, 3), 125.70 (p-Ph, toluene), 65.28 (tetraarylmethyl, tentatively 1-(diphenylmethyl)-4(trityl)benzene, B), 65.19, 58.93, 58.64 (ternary C, tentatively 1-(diphenylmethyl)-4(trityl)benzene, B), $57.29\left(\mathrm{Ph}_{3} \mathrm{CH}, \mathrm{A}\right), 56.92,46.85,46.78,21.45\left(\mathrm{CH}_{3} \mathrm{C}_{6} \mathrm{H}_{5}\right.$, toluene).

Synthesis of 3 from Ni(PPh $)_{4}$. A J. Young NMR tube was charged with $\mathrm{Ni}\left(\mathrm{PPh}_{3}\right)_{4}(7.3$ $\mathrm{mg}, 0.0086 \mathrm{mmol})$ and $\mathrm{C}_{6} \mathrm{D}_{6}(1 \mathrm{~mL})$ to provide a red-orange solution. This sample was 
transferred out of the glove box, and the solution was then heated at $40^{\circ} \mathrm{C}$ for $19 \mathrm{~h}$, whereupon the solution turned red-brown concomitant with the deposition of a small amount of black solid. The solution was then heated at $80^{\circ} \mathrm{C}$ for $25 \mathrm{~h}$, which resulted in a color change to brown, without further deposition of solids. ${ }^{1} \mathrm{H}$ and ${ }^{31} \mathrm{P}\left\{{ }^{1} \mathrm{H}\right\} \mathrm{NMR}$ spectra were collected at the specified temperatures and times (see Figure S16).

Modified Synthesis of Gomberg's Dimer: In a $20 \mathrm{~mL}$ vial equipped with a magnetic stir bar, triphenylmethyl chloride (0.8301 $\mathrm{mg}, 2.978 \mathrm{mmol}$ ) was dissolved in toluene (17 mL). Zn powder (509 $\mathrm{mg}, 7.79 \mathrm{mmol}$ ) was then added as a solid, whereupon the color changed to dark yellow over the course of several minutes. After $12 \mathrm{~h}$, the yellow hue of the solution had darkened concomitant with the deposition of a brown solid, consistent with the observations of Gomberg. ${ }^{6}$ Filtration of this solution through a Celite column supported on glass wool $(0.5 \mathrm{~cm} \times 5 \mathrm{~cm})$ furnished a yellow filtrate that was concentrated to $3 \mathrm{~mL}$. Layering of this solution with $17 \mathrm{~mL}$ hexanes and subsequent storage at $-25^{\circ} \mathrm{C}$ for $18 \mathrm{~h}$ resulted in the deposition of pale yellow crystals of Gomberg's dimer. A pale yellow supernatant was decanted and discarded, and the crystals were dried under vacuum. This material was then dissolved toluene ( $3 \mathrm{~mL})$, layered with pentane $(17 \mathrm{~mL})$, and stored at $-25{ }^{\circ} \mathrm{C}$ for $18 \mathrm{~h}$, which resulted in the deposition of pale yellow crystals of Gomberg's dimer (460.7 mg, 64\% yield). ${ }^{1} \mathrm{H}$ NMR (400 MHz, $\mathrm{CD}_{2} \mathrm{Cl}_{2}, 25^{\circ} \mathrm{C}$ ): $\delta$ 7.46-7.17 (m, overlapping aryl $\mathrm{CH}$ overlapping with br s, 21H), 7.07 (d, o-Ph, vinylic phenyl, 4H), 6.34 (d, vinylic $\mathrm{CH}, 2 \mathrm{H}$ ), 6.09 (d, vinylic $\mathrm{CH}$, 2H), 5.22 (d, allylic $\mathrm{CH}, 1 \mathrm{H}) .{ }^{13} \mathrm{C}$ NMR $\left(101 \mathrm{MHz}, \mathrm{CD}_{2} \mathrm{Cl}_{2}, 25{ }^{\circ} \mathrm{C}\right): \delta 142.25$ (ipso $\mathrm{Ph}$ ), 137.85 (ipso Ph), 130.94 (o-Ph, vinylic phenyl), 130.64 (vinylic C), 129.54 (Ph), 
129.22 (vinylic C), $128.74(\mathrm{Ph}), 128.45(\mathrm{Ph}), 128.41(\mathrm{Ph}), 128.37(\mathrm{Ph}), 127.77(\mathrm{Ph})$, 127.39 (Ph), $126.42(\mathrm{Ph}), 126.42(\mathrm{Ph}), 44.19$ (allylic C).

X-ray Crystallography. Data for $\mathbf{1}$ and $\mathbf{3} \cdot 2 \mathrm{C}_{7} \mathrm{H}_{8}$ were collected on a Bruker KAPPA APEX II diffractometer equipped with an APEX II CCD detector using a TRIUMPH monochromater with a MoK $\alpha$ X-ray source $(\alpha=0.71073 \AA$ A $)$. Crystals were mounted on a cryoloop under Paratone-N oil, and all data were collected at 110(2) K using an Oxford nitrogen gas cryostream system. X-ray data for $\mathbf{1}$ and $\mathbf{3} \cdot 2 \mathrm{C}_{7} \mathrm{H}_{8}$ were collected utilizing frame exposures of $30 \mathrm{~s}$ and $10 \mathrm{~s}$, respectively. Data collection and cell parameter determination were conducted using the SMART program. ${ }^{7}$ Integration of the data frames and final cell parameter refinement were performed using SAINT software. ${ }^{8}$ Absorption correction of the data was carried out using the multi-scan method SADABS. ${ }^{9}$ Subsequent calculations were carried out using SHELXTL. ${ }^{10}$ Structure determination was done using direct methods and difference Fourier techniques. All hydrogen atom positions were idealized, and rode on the atom of attachment. Structure solution, refinement, graphics, and creation of publication materials were performed using SHELXTL. ${ }^{10}$

For complex 1, the EADP command was used to constrain the anisotropic displacement parameters of carbon atom pairs related by the inversion center at Ni1. In addition, the SADI command was used to constrain the distances between C20 and C33, as well C39 and C46. Finally, the crystal of $\mathbf{1}$ was found to be an inversion twin, which necessitated the use of the TWIN and BASF commands.

For complex $3 \cdot 2 \mathrm{C}_{7} \mathrm{H}_{8}$, the two $\mathrm{C}_{7} \mathrm{H}_{8}$ solvate molecules were found to be disordered over two positions, which were each modelled in 50:50 ratio. The alternate positions 
were related by a $180^{\circ}$ rotation about the center of the ring. The para $\mathrm{H}$ atoms of these solvate molecules were not assigned due to positional disorder between para and ipso carbon atoms. In addition, the carbons of one disordered toluene solvate (C96, C97, C98, C99) were refined isotropically.

Further crystallographic details can be found in Table S1. Complexes $\mathbf{1}$ and $3 \cdot 2 \mathrm{C}_{7} \mathrm{H}_{8}$ have been deposited in the Cambridge Structural Database (1: CCDC 1982483; 3.2C $\mathrm{CH}_{8}$ : CCDC 1982484). 
Table S1. X-ray Crystallographic Data for 1 and 3.2 $\mathrm{C}_{7} \mathrm{H}_{8}$

\begin{tabular}{|c|c|c|}
\hline & 1 & $3 \cdot 2 \mathrm{C}_{7} \mathrm{H}_{8}$ \\
\hline empirical formula & $\mathrm{NiC}_{38} \mathrm{H}_{30}$ & $\mathrm{Ni}_{3} \mathrm{P}_{6} \mathrm{C}_{98} \mathrm{H}_{86}$ \\
\hline crystal habit, color & Plate, purple & Plate, brown \\
\hline crystal size $(\mathrm{mm})$ & $0.35 \times 0.35 \times 0.05$ & $0.20 \times 0.15 \times 0.10$ \\
\hline crystal system & Monoclinic & Triclinic \\
\hline space group & $\mathrm{P} n$ & $\mathrm{P} \overline{1}$ \\
\hline volume $\left(\AA^{3}\right)$ & 2666.2 & 4036.7 \\
\hline$a(\AA)$ & $10.8357(19)$ & $13.629(3)$ \\
\hline$b(\AA)$ & $11.0954(19)$ & $14.661(4)$ \\
\hline$c(\AA)$ & $22.820(4)$ & $21.826(5)$ \\
\hline$\alpha(\mathrm{deg})$ & 90 & $76.796(7)$ \\
\hline$\beta$ (deg) & $103.639(3)$ & $73.925(6)$ \\
\hline$\gamma(\mathrm{deg})$ & 90 & 78.516(7) \\
\hline $\mathrm{Z}$ & 4 & 2 \\
\hline formula weight (g/mol) & 545.31 & 1625.61 \\
\hline density (calculated) $\left(\mathrm{Mg} / \mathrm{m}^{3}\right)$ & 1.359 & 1.337 \\
\hline absorption coefficient $\left(\mathrm{mm}^{-1}\right)$ & 0.754 & 0.860 \\
\hline $\mathrm{F}_{000}$ & 1144 & 1696 \\
\hline total no. reflections & 10189 & 16235 \\
\hline unique reflections & 7871 & 9858 \\
\hline \multirow[t]{2}{*}{ final $R$ indices $[I>2 \sigma(I)]$} & $\mathrm{R}_{1}=0.1025$ & $\mathrm{R}_{1}=0.0554$ \\
\hline & $w_{2}=0.2347$ & $w R_{2}=0.1464$ \\
\hline largest diff. peak and hole $\left(\mathrm{e}^{-} \mathrm{A}^{-3}\right)$ & 1.163 and -0.783 & 1.163 and -0.783 \\
\hline GOF & 1.109 & 0.976 \\
\hline
\end{tabular}




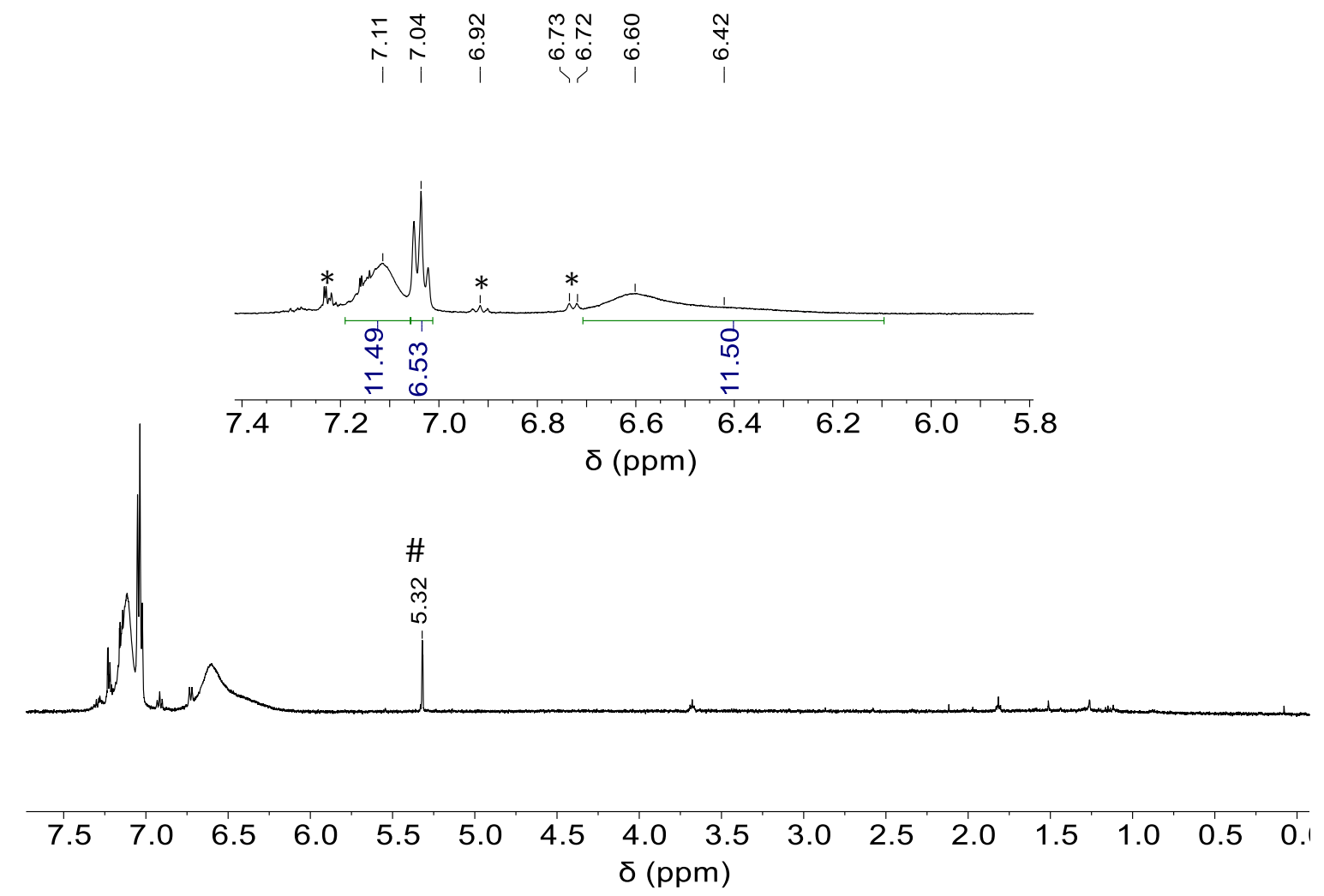

Figure S1. ${ }^{1} \mathrm{H}$ NMR spectrum of $\mathrm{Ni}\left(\eta^{3}-\mathrm{CPh}_{3}\right)_{2}(\mathbf{1})$ in $\mathrm{CD}_{2} \mathrm{Cl}_{2}$ at room temperature. (\#) indicates a resonance assignable to methylene chloride. $(*)$ indicates resonances assignable to an unidentified impurity. 

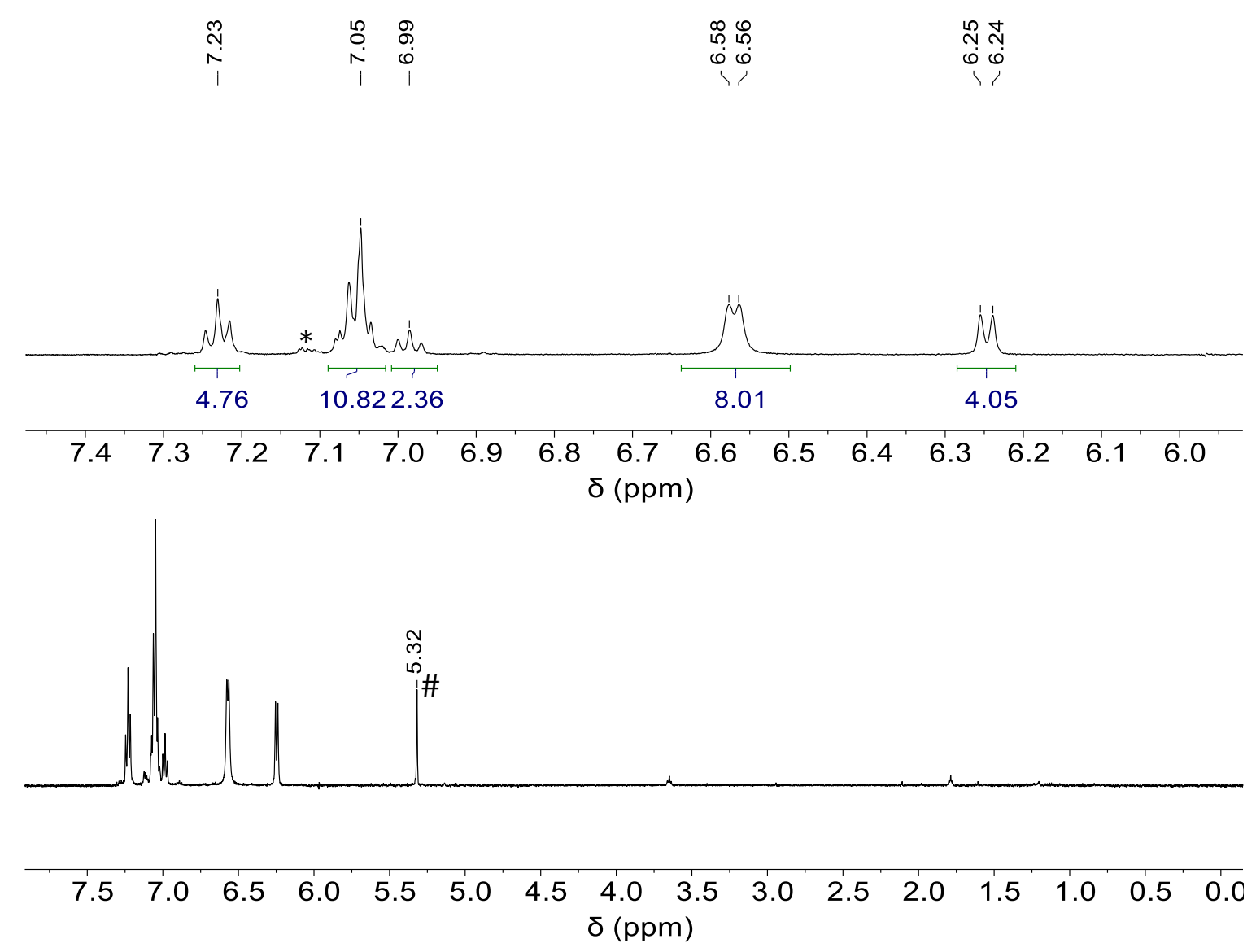

Figure S2. ${ }^{1} \mathrm{H}$ NMR spectrum of $\mathrm{Ni}\left(\eta^{3}-\mathrm{CPh}_{3}\right)_{2}(\mathbf{1})$ in $\mathrm{CD}_{2} \mathrm{Cl}_{2}$ at $-40^{\circ} \mathrm{C}$. (\#) indicates a resonance assignable to methylene chloride. $\left({ }^{*}\right)$ indicates resonances assignable to an unidentified impurity. 

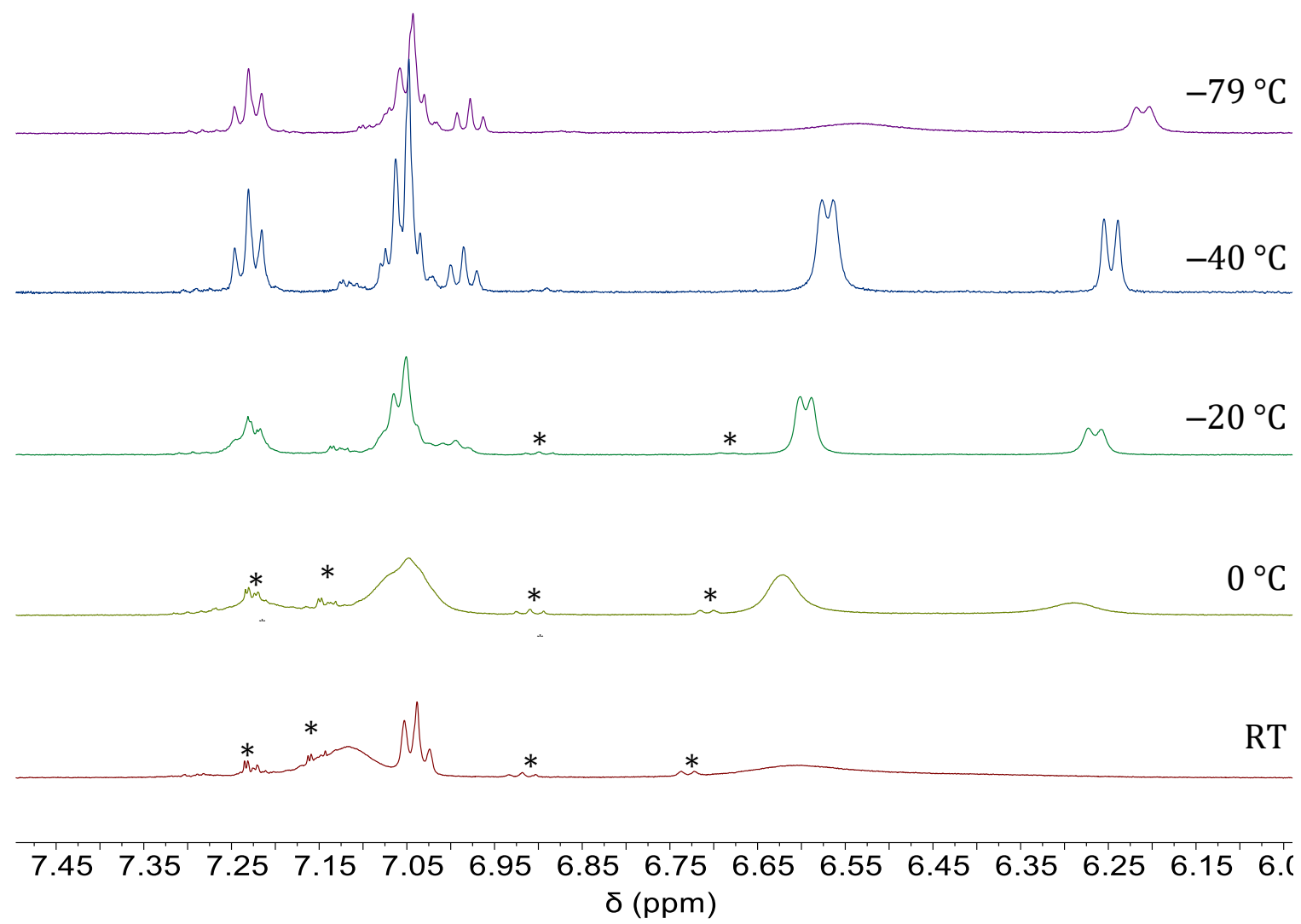

Figure S3. Variable temperature ${ }^{1} \mathrm{H}$ NMR spectra of $\mathrm{Ni}\left(\eta^{3}-\mathrm{CPh}_{3}\right)_{2}(\mathbf{1})$ in $\left.\mathrm{CD}_{2} \mathrm{Cl}_{2} \cdot{ }^{*}\right)$ indicates resonances assignable to an unidentified impurity. 


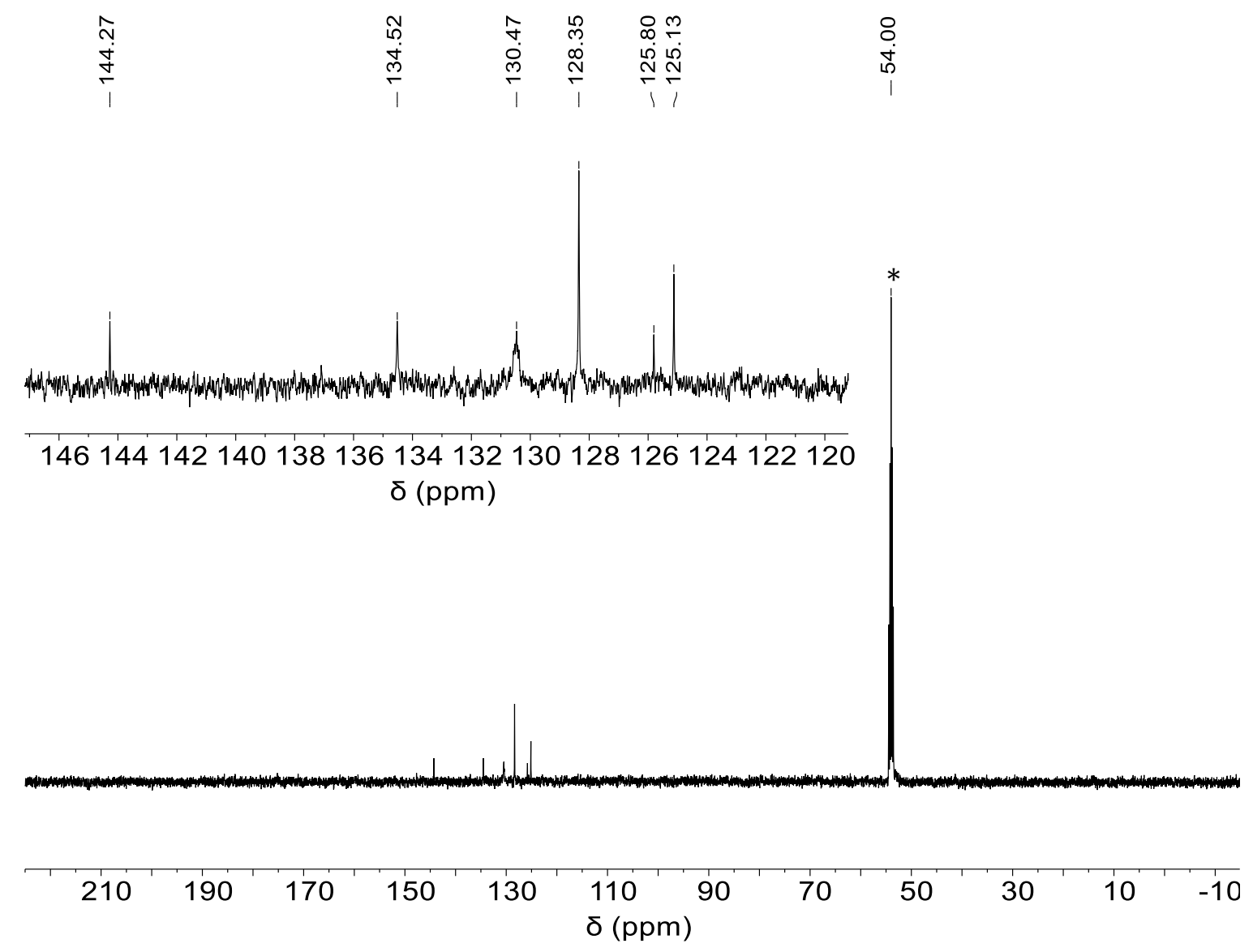

Figure S4. ${ }^{13} \mathrm{C}\left\{{ }^{1} \mathrm{H}\right\}$ NMR spectrum of $\mathrm{Ni}\left(\eta^{3}-\mathrm{CPh}_{3}\right)_{2}(\mathbf{1})$ in $\mathrm{CD}_{2} \mathrm{Cl}_{2}$ at $-40{ }^{\circ} \mathrm{C} .\left(^{*}\right)$

indicates a resonance assignable to methylene chloride- $d_{2}$. 


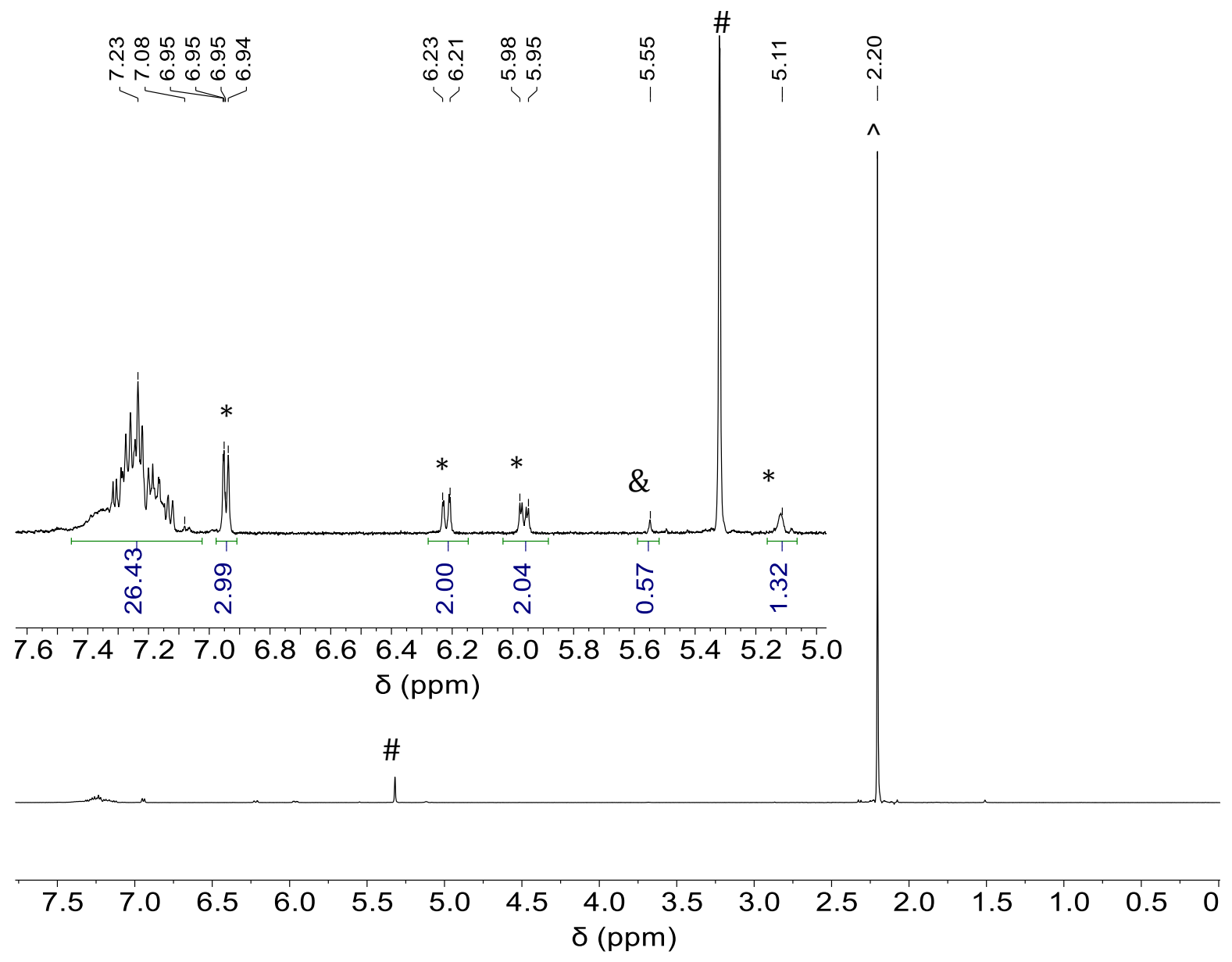

Figure S5. ${ }^{1 \mathrm{H}} \mathrm{NMR}$ spectrum $\left(\mathrm{CD}_{2} \mathrm{Cl}_{2}\right.$, room temperature $)$ of the reaction of $\mathrm{Ni}\left(\eta^{3}-\right.$ $\left.\mathrm{CPh}_{3}\right)_{2}$ (1) with excess $\mathrm{CO}$ gas after 10 min, with hexamethylbenzene added as an internal standard. (\#) indicates a resonance assignable to methylene chloride. $\left({ }^{*}\right)$ indicates a resonance assignable to Gomberg's dimer. (\&) indicates a resonance assignable to triphenylmethane. $\left({ }^{\wedge}\right)$ indicates a resonance assignable to hexamethylbenzene. 


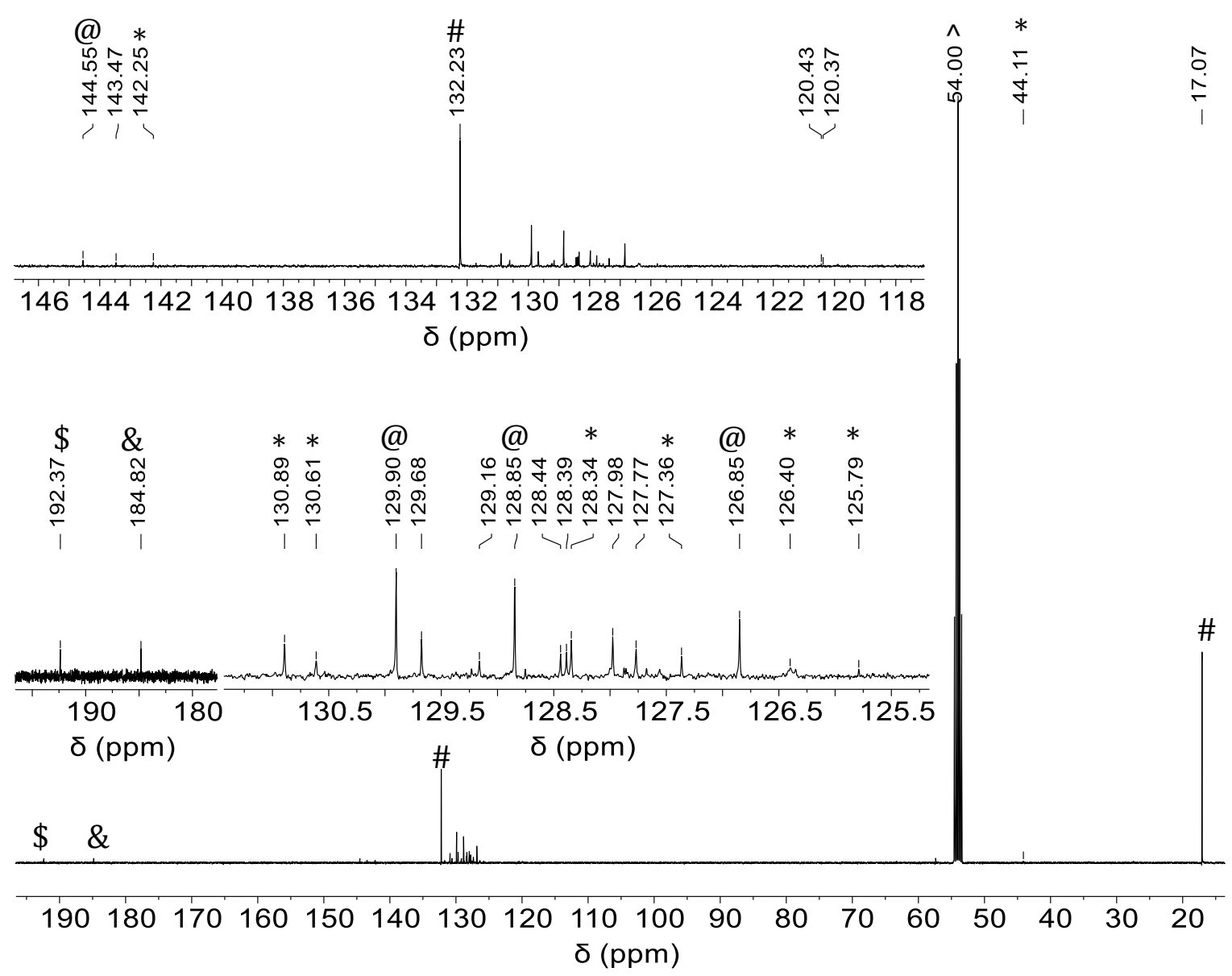

Figure S6. ${ }^{13} \mathrm{C}\left\{{ }^{1} \mathrm{H}\right\}$ NMR spectrum $\left(\mathrm{CD}_{2} \mathrm{Cl}_{2}\right.$, room temperature) of the reaction of $\mathrm{Ni}\left(\eta^{3}-\mathrm{CPh}_{3}\right)_{2}(\mathbf{1})$ with excess $\mathrm{CO}$ recorded after $10 \mathrm{~h}$. (\#) indicates a resonance assignable to hexamethylbenzene. $\left({ }^{\wedge}\right)$ indicates a resonance assignable to methylene chloride. $(\$)$ indicates a resonance assignable to $\mathrm{Ni}(\mathrm{CO}) 4 .{ }^{4}(\&)$ indicates a resonance assignable to dissolved $\mathrm{CO}$ gas. $\left.{ }^{3}{ }^{*}\right)$ indicates resonances assignable to Gomberg's dimer. ${ }^{3}$ (@) indicates resonances assignable to triphenylmethane. Peaks without an symbol remain unassigned. 
竎鱼造

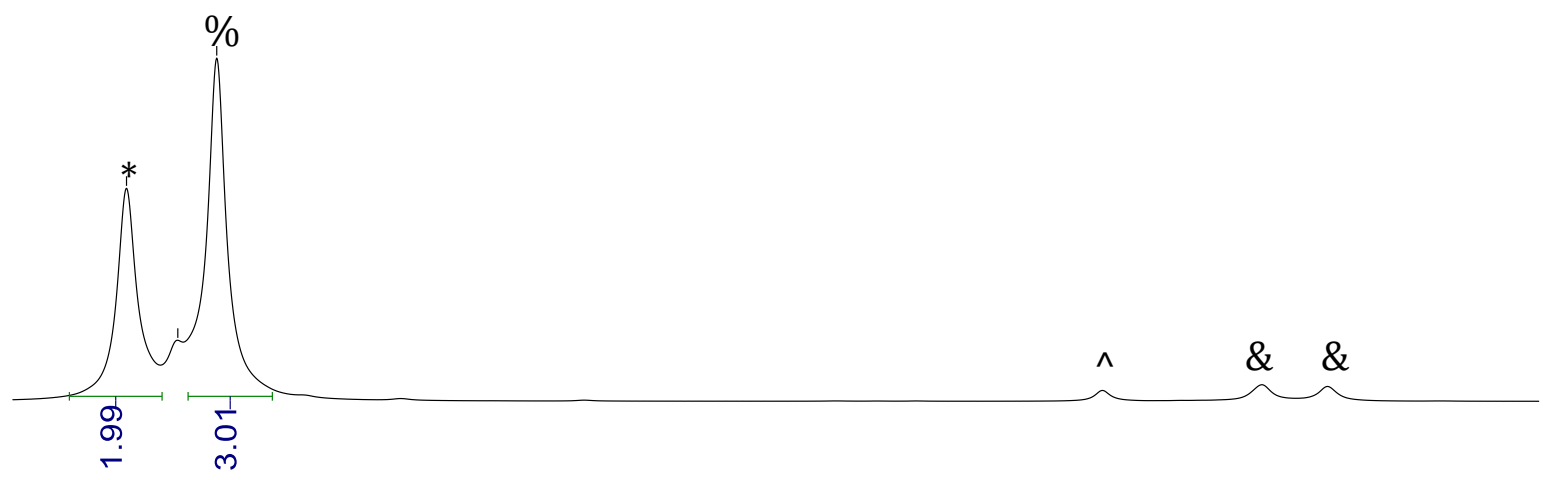

$\begin{array}{llllllllllllllllll}3.0 & 7.5 & 7.0 & 6.5 & 6.0 & 5.5 & 5.0 & 4.5 & 4.0 & 3.5 & 3.0 & 2.5 & 2.0 & 1.5 & 1.0 & 0.5 & 0.0\end{array}$ $\delta$ (ppm)

Figure S7. ${ }^{1} \mathrm{H}$ NMR spectrum of $\mathrm{Ni}\left(\mathrm{PPh}_{3}\right)_{4}(2)$ in $\mathrm{C}_{6} \mathrm{D}_{6}$ at room temperature. $\left({ }^{*}\right)$ and (\%) are resonances assignable to meta/ortho phenyl peaks and meta/ortho and para phenyl peaks, respectively. ${ }^{2}\left({ }^{\wedge}\right)$ indicates a resonance assignable to toluene. $(\&)$ indicate resonances assignable to hexanes. 


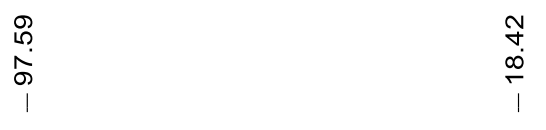

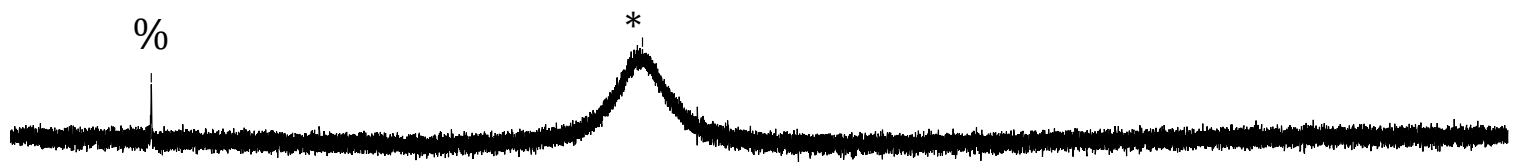

$20100 \quad 80 \quad 60 \quad 40 \quad 20 \begin{gathered}0 \\ \delta(\mathrm{ppm})\end{gathered}$

Figure S8. ${ }^{31} \mathrm{P}\left\{{ }^{1} \mathrm{H}\right\} \mathrm{NMR}$ spectrum of $\mathrm{Ni}\left(\mathrm{PPh}_{3}\right)_{4}(2)$ in $\mathrm{C}_{6} \mathrm{D}_{6}$ at room temperature. $\left(^{*}\right)$ indicates a resonances assignable to $\mathrm{Ni}\left(\mathrm{PPh}_{3}\right)_{4}(2) \cdot{ }^{2}(\%)$ indicates a resonance tentatively assigned to $\left[\mathrm{Ni}_{2}\left(\mu-\mathrm{PPh}_{2}\right)_{2}\left(\mathrm{PPh}_{3}\right)_{3}\right](4) \cdot{ }^{11}$ 


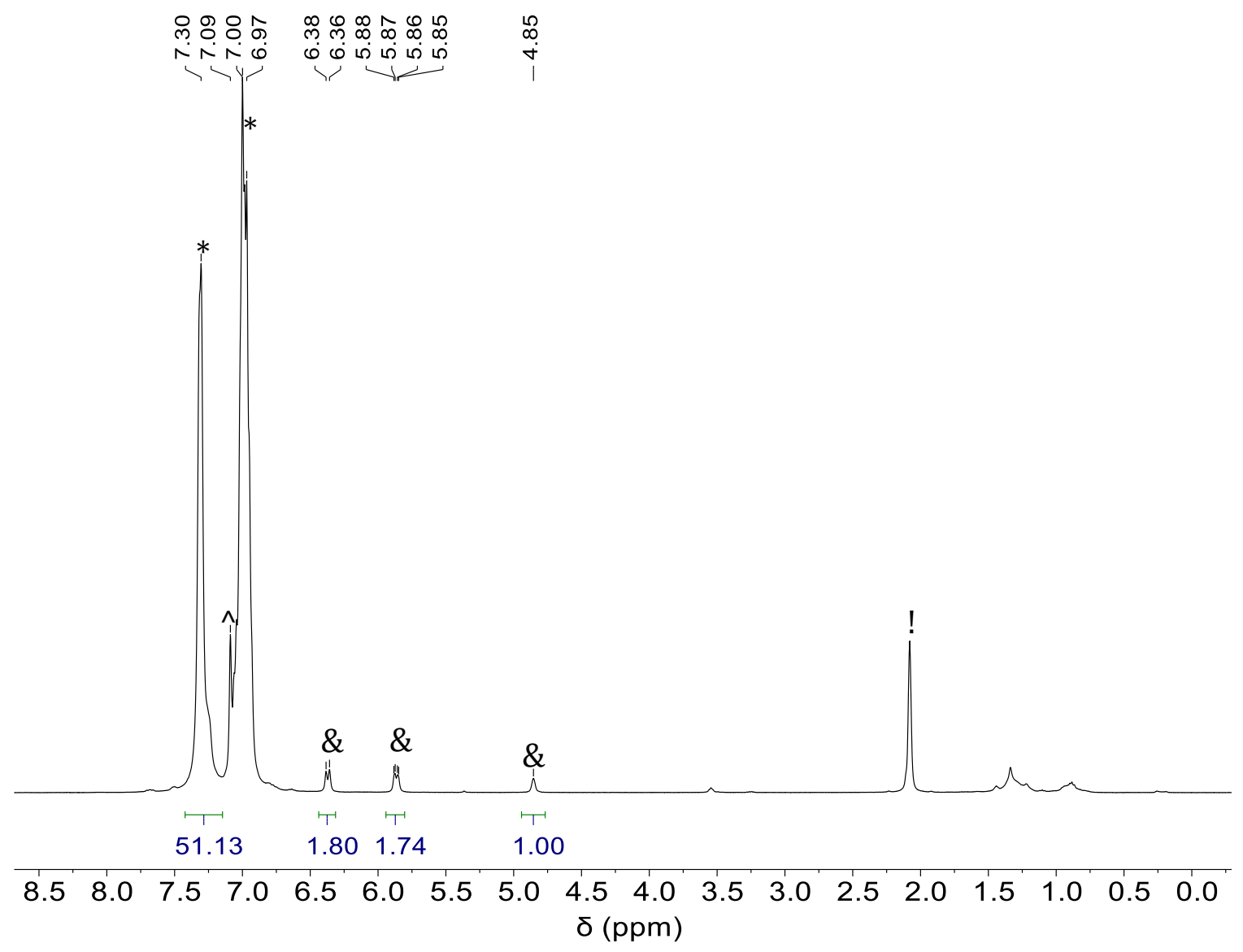

Figure S9. ${ }^{1} \mathrm{H}$ NMR spectrum of the reaction of 1 with 4 equiv of $\mathrm{PPh}_{3}$ in toluene- $d_{8}$ at room temperature after $18 \mathrm{~h} .\left(^{*}\right)$ indicates resonances assignable to $\mathrm{Ni}\left(\mathrm{PPh}_{3}\right)_{4}$ $(2) \cdot{ }^{2}(\wedge)$ indicates a resonance assignable to benzene. (\&) indicates a resonances assignable to Gomberg's dimer. (!) indicates a resonance assignable to toluene. 

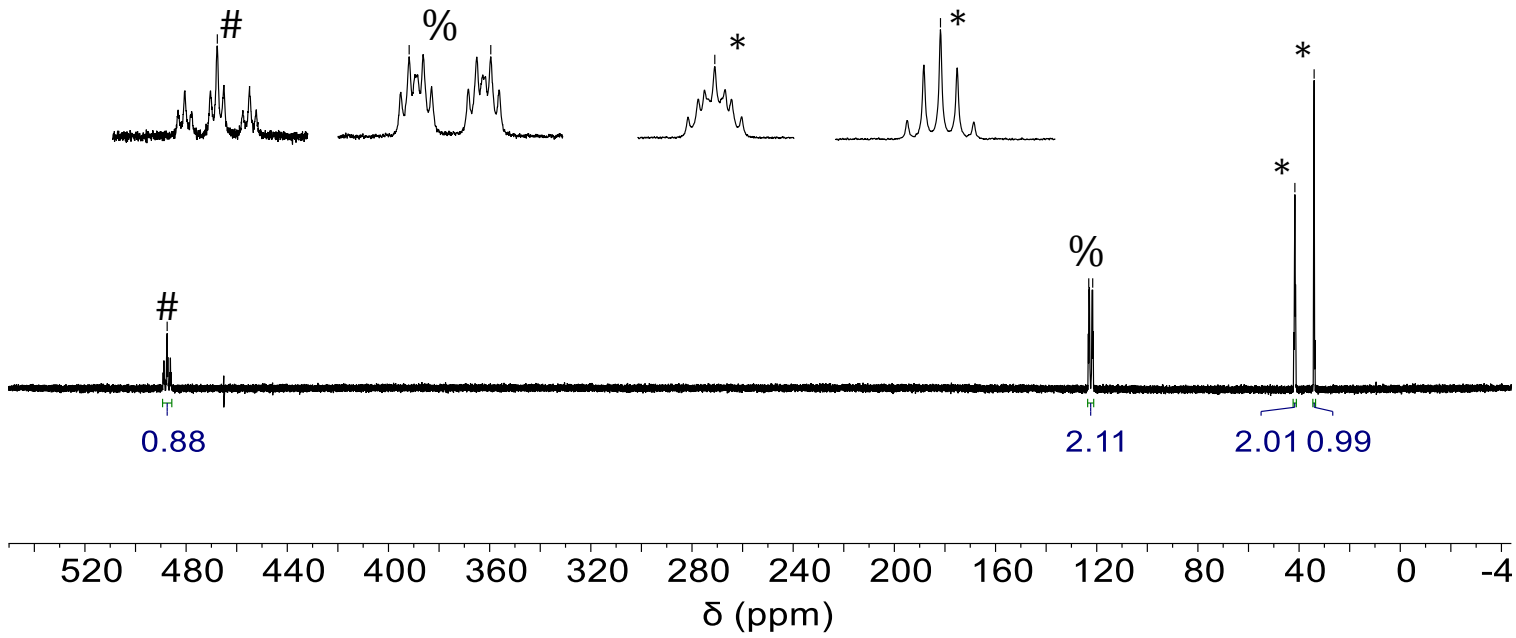

Figure S10. ${ }^{31} \mathrm{P}\left\{{ }^{1} \mathrm{H}\right\}$ NMR spectrum of $\left[\mathrm{Ni}_{3}\left(\mu_{3}-\mathrm{PPh}\right)\left(\mu-\mathrm{PPh}_{2}\right)_{2}\left(\mathrm{PPh}_{3}\right)_{3}\right](3)$ in $\mathrm{C}_{6} \mathrm{D}_{6}$ at room temperature. (\#), (\%), and $\left({ }^{*}\right)$ indicate resonances assignable to the phosphinidene $\left(\mu_{3}-\mathrm{PPh}\right)$, phosphide $\left(\mu-\mathrm{PPh}_{2}\right)$, and phosphine $\left(\mathrm{PPh}_{3}\right)$ ligands, respectively. 

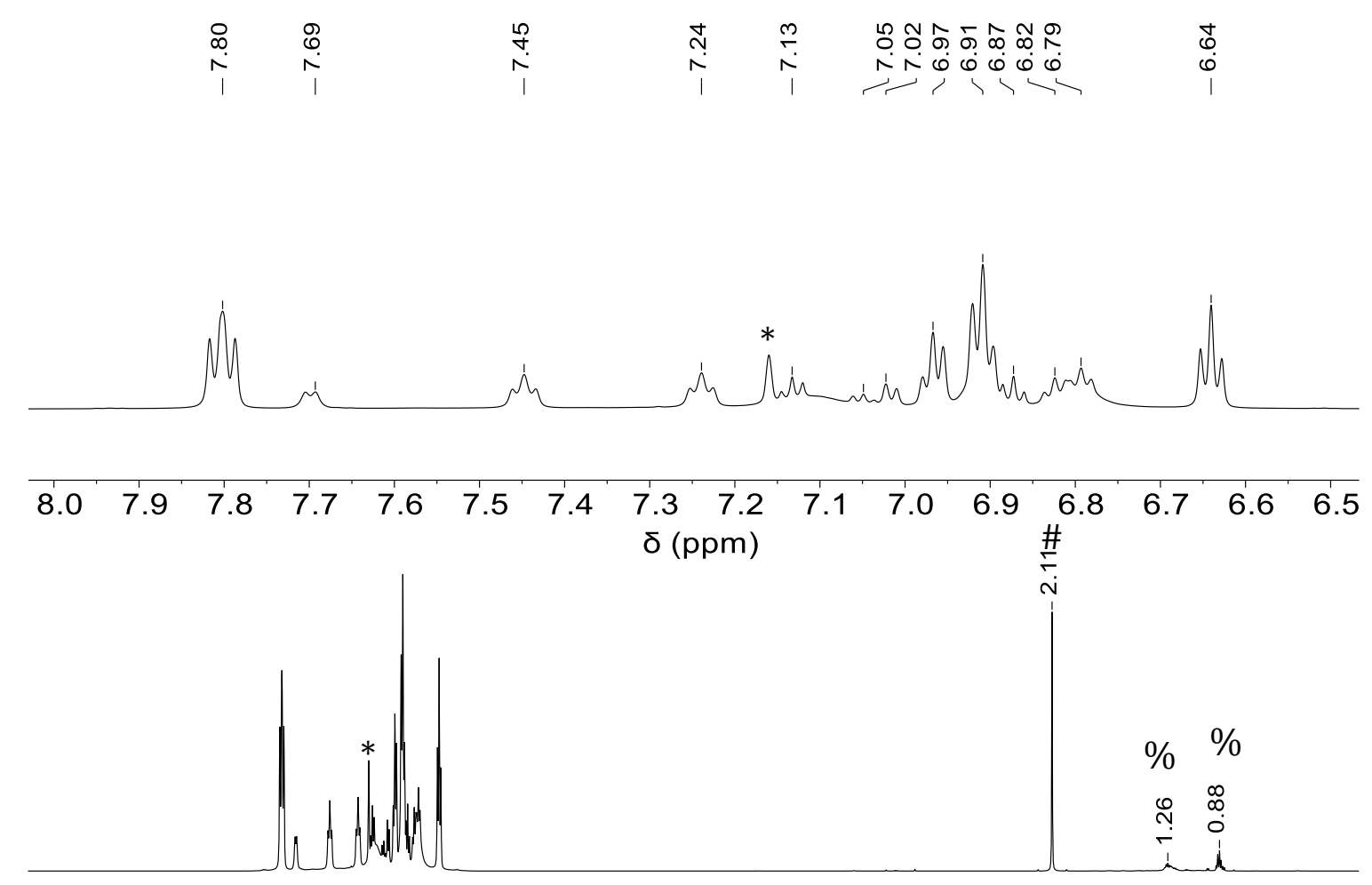

$\begin{array}{cccccccccccccccccccccccc}9.5 & 9.0 & 8.5 & 8.0 & 7.5 & 7.0 & 6.5 & 6.0 & 5.5 & 5.0 & 4.5 & 4.0 & 3.5 & 3.0 & 2.5 & 2.0 & 1.5 & 1.0 & 0.5 & 0.1 \\ & & & \end{array}$

Figure S11. ${ }^{1} \mathrm{H}$ NMR spectrum of $\left[\mathrm{Ni}_{3}\left(\mu_{3}-\mathrm{PPh}\right)\left(\mu-\mathrm{PPh}_{2}\right)_{2}\left(\mathrm{PPh}_{3}\right)_{3}\right](\mathbf{3})$ in $\mathrm{C}_{6} \mathrm{D}_{6}$ at room temperature. (\#) indicate a resonance assignable to toluene. $\left({ }^{*}\right)$ indicate a resonance assignable to benzene. (\%) indicate resonances assignable to hexanes. 

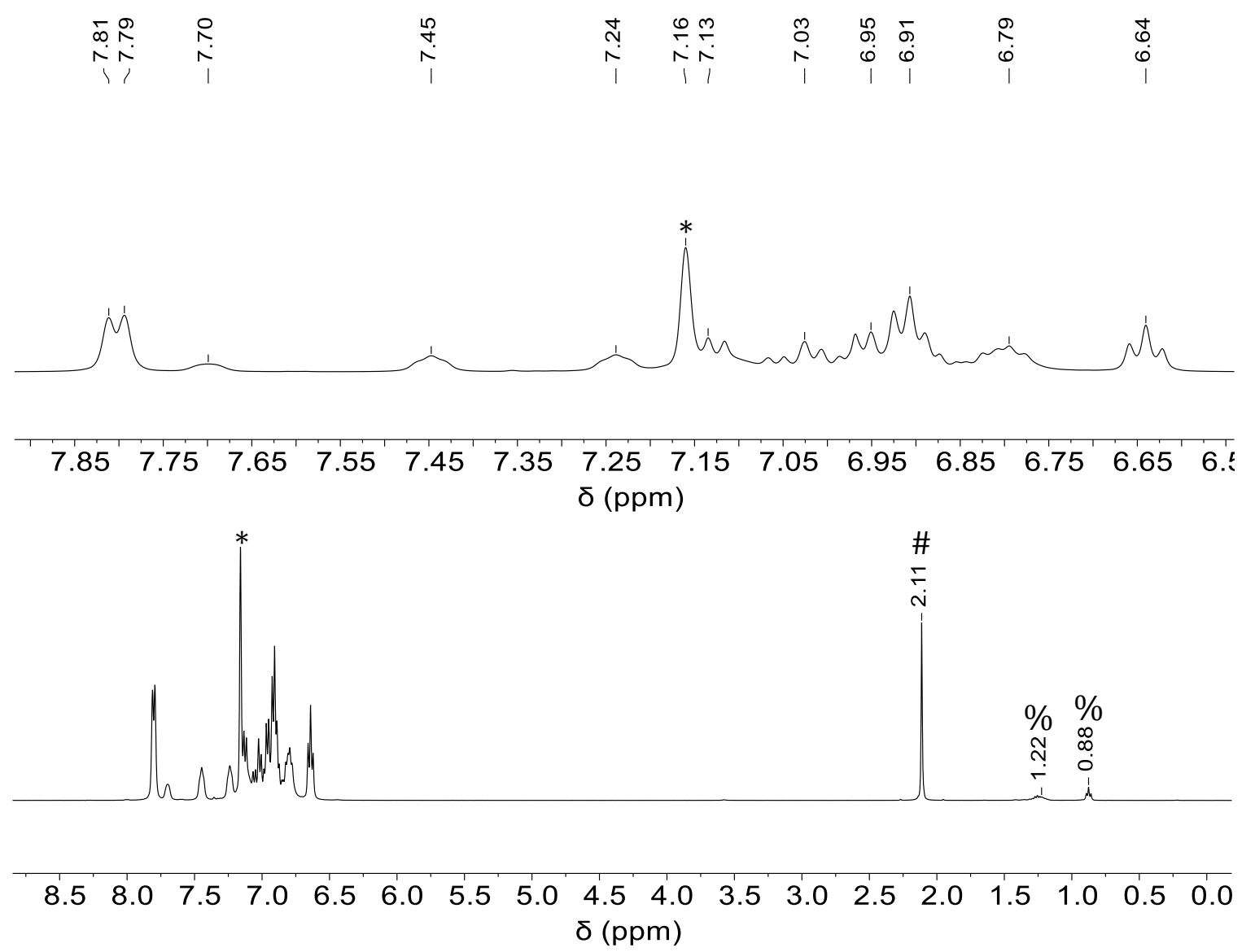

Figure S12. ${ }^{1} \mathrm{H}\left\{{ }^{31} \mathrm{P}\right\}$ NMR spectrum of $\left[\mathrm{Ni}_{3}\left(\mu_{3}-\mathrm{PPh}\right)\left(\mu-\mathrm{PPh}_{2}\right)_{2}\left(\mathrm{PPh}_{3}\right)_{3}\right](3)$ in $\mathrm{C}_{6} \mathrm{D}_{6}$ at room temperature. (\#) indicate a resonance assignable to toluene. $\left({ }^{*}\right)$ indicate a resonance assignable to benzene. (\%) indicate resonances assignable to pentane. 


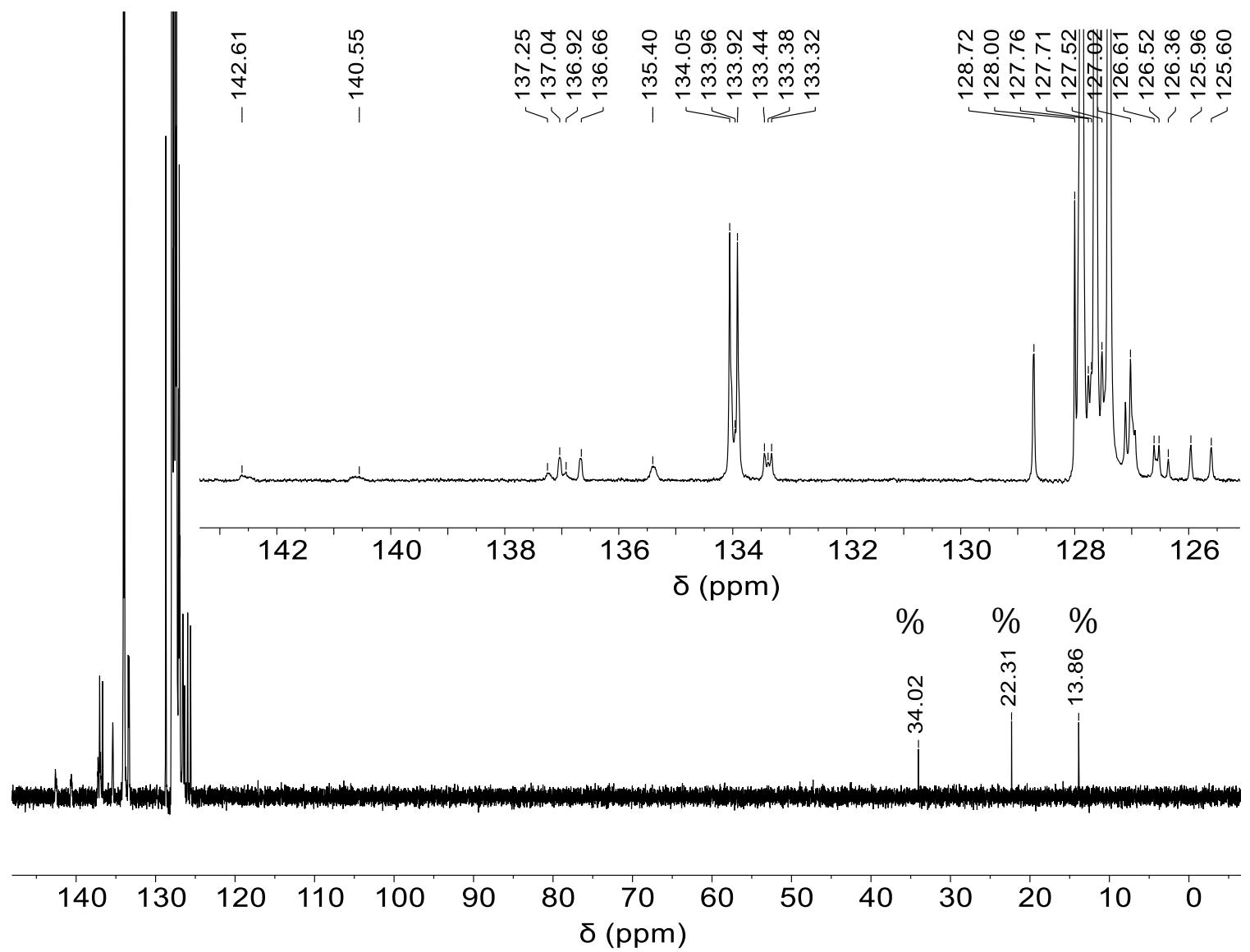

Figure S13. ${ }^{13} \mathrm{C}\left\{{ }^{1} \mathrm{H}\right\}$ NMR spectrum of $\left[\mathrm{Ni}_{3}\left(\mu_{3}-\mathrm{PPh}\right)\left(\mu-\mathrm{PPh}_{2}\right)_{2}\left(\mathrm{PPh}_{3}\right)_{3}\right](3)$ in $\mathrm{C}_{6} \mathrm{D}_{6}$ at room temperature. (\%) indicate resonances assignable to pentane. 

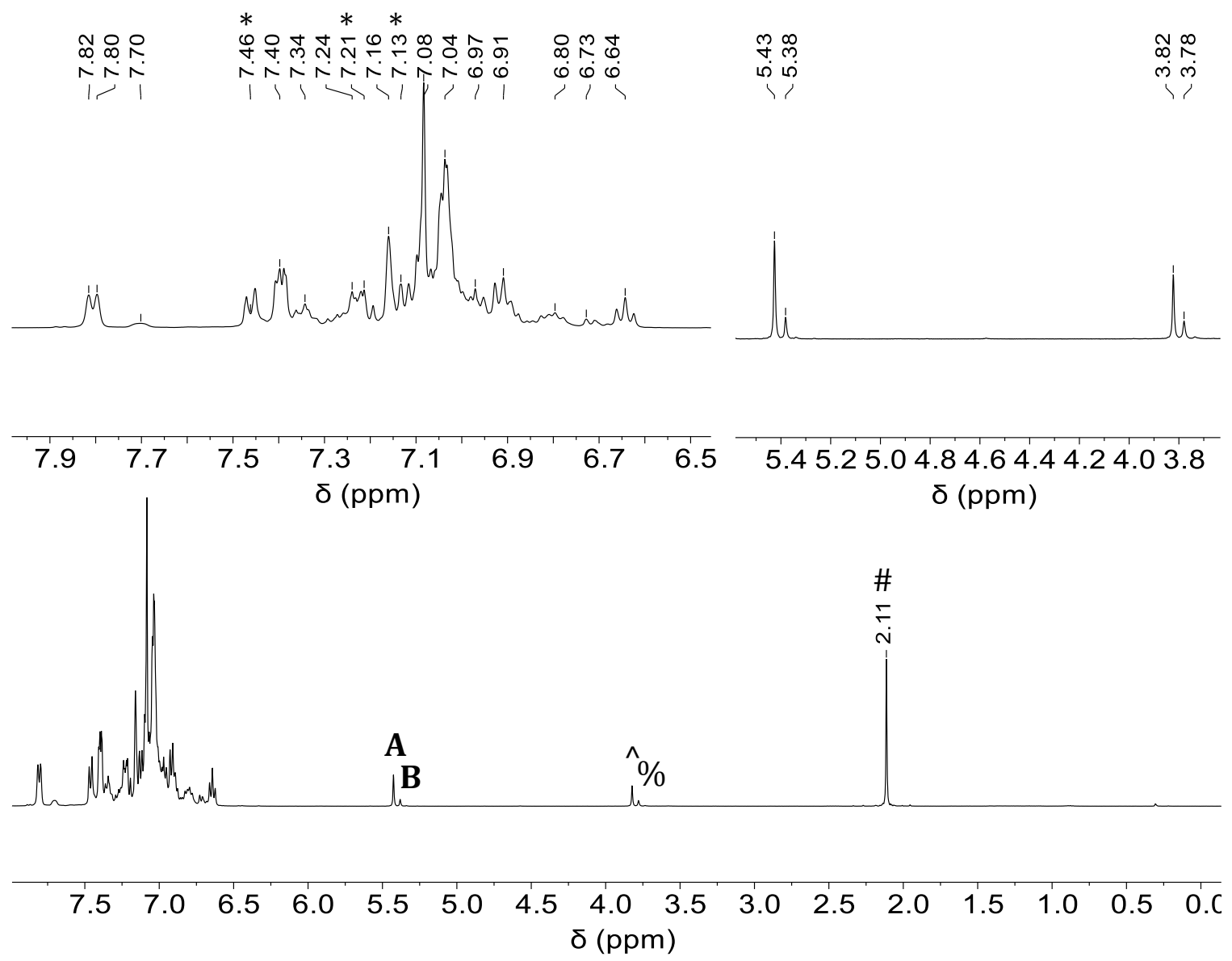

Figure S14. ${ }^{1} \mathrm{H}\left\{{ }^{31} \mathrm{P}\right\}$ NMR spectrum of crude reaction mixture from the synthesis of $\left[\mathrm{Ni}_{3}\left(\mu_{3}-\mathrm{PPh}\right)\left(\mu-\mathrm{PPh}_{2}\right)_{2}\left(\mathrm{PPh}_{3}\right)_{3}\right](3)$, recorded in $\mathrm{C}_{6} \mathrm{D}_{6}$ at room temperature. (\#) indicates a resonance assignable to toluene. (A) indicates a resonance assignable to triphenylmethane $\left(\mathrm{Ph}_{3} \mathrm{CH}\right)$. (B) indicates a resonance assignable to 1(diphenylmethyl)-4-(trityl)benzene. ${ }^{12}(*)$ indicates a resonances assignable to biphenyl. $\left({ }^{\wedge}\right)$ and $(\%)$ indicate resonances assigned to unknown decomposition products of Gomberg's dimer. 


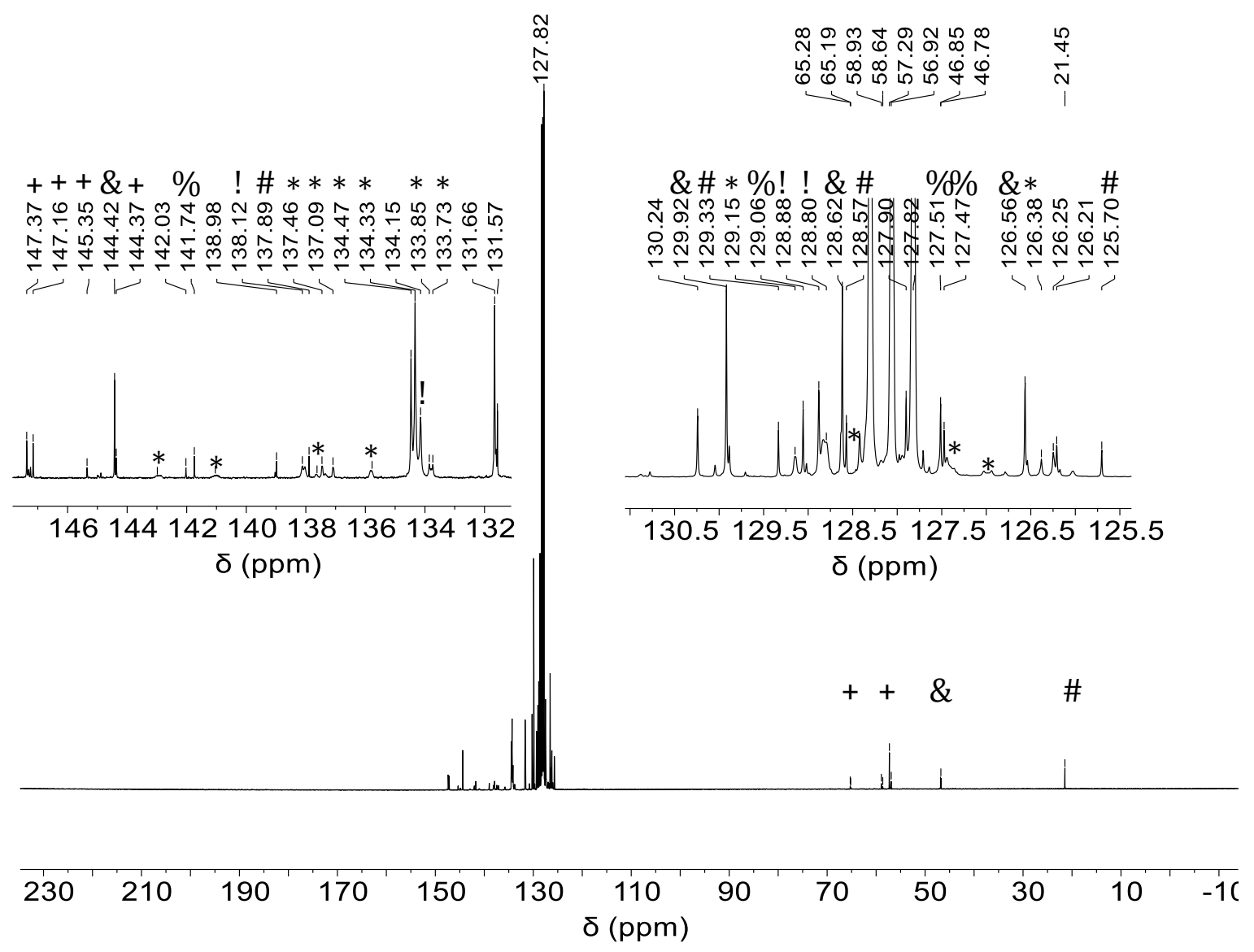

Figure S15. ${ }^{13} \mathrm{C}\left\{{ }^{1} \mathrm{H}\right\}$ NMR spectrum of crude reaction mixture from the synthesis of $\left[\mathrm{Ni}_{3}\left(\mu_{3}-\mathrm{PPh}\right)\left(\mu-\mathrm{PPh}_{2}\right)_{2}\left(\mathrm{PPh}_{3}\right)_{3}\right](3)$, recorded in $\mathrm{C}_{6} \mathrm{D}_{6}$ at room temperature. (\#) indicates a resonance assignable to toluene. ${ }^{13}(\&)$ indicates a resonance assignable to triphenylmethane (A). (\%) indicates a resonance assignable to biphenyl. ${ }^{*}$ ) indicates resonances assignable to 3. (!) indicates a resonance assignable to triphenylphosphine. (+) indicates resonances tentatively assigned to 1(diphenylmethyl)-4-(trityl)benzene (B). ${ }^{12}$ Peaks without a symbol remain unassigned. 


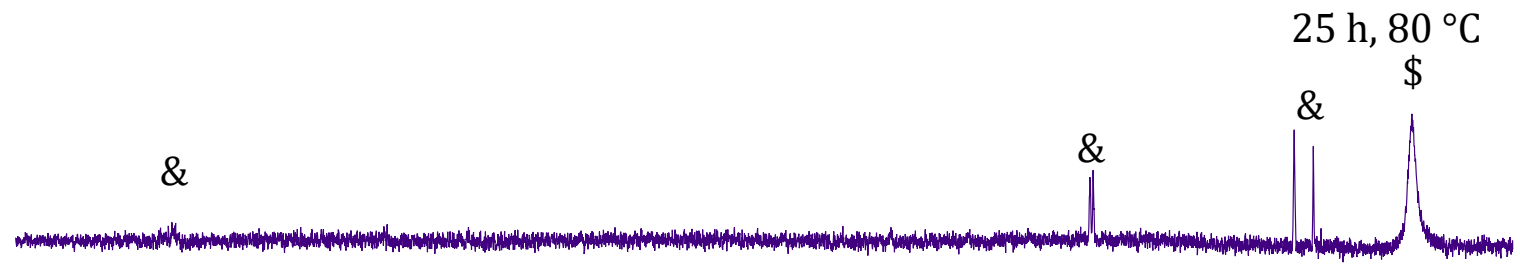

$19 \mathrm{~h}, 40^{\circ} \mathrm{C}$
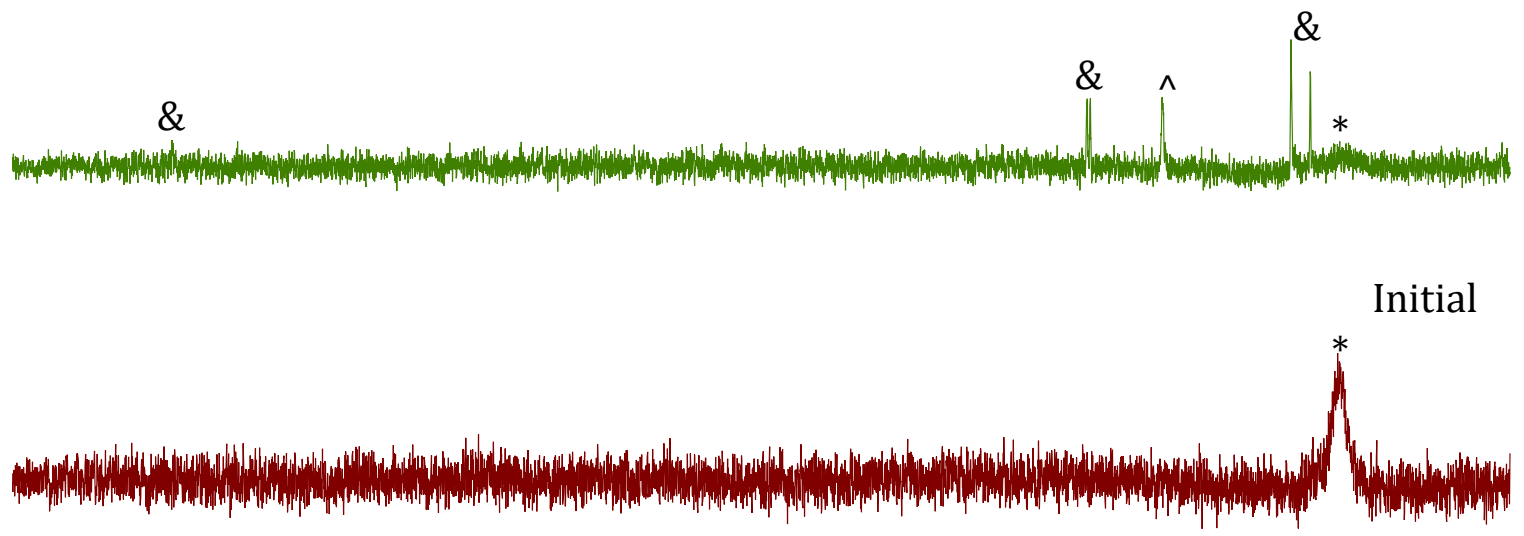

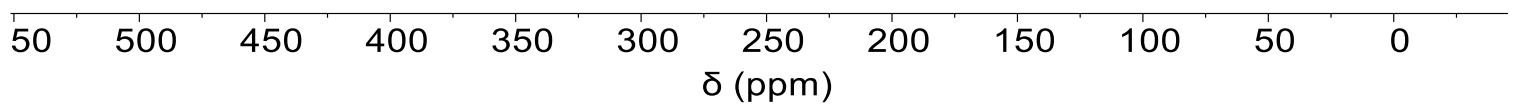

Figure S16. ${ }^{31} \mathrm{P}\left\{{ }^{1} \mathrm{H}\right\}$ NMR spectra of the thermolysis of $\mathrm{Ni}\left(\mathrm{PPh}_{3}\right)_{4}(2)$ in $\mathrm{C}_{6} \mathrm{D}_{6} .\left(^{*}\right)$ indicates resonances assignable to $\mathrm{Ni}\left(\mathrm{PPh}_{3}\right)_{4}$. (\&) indicates resonances assignable to $\left[\mathrm{Ni}_{3}\left(\mu_{3}-\mathrm{PPh}\right)\left(\mu-\mathrm{PPh}_{2}\right)_{2}\left(\mathrm{PPh}_{3}\right)_{3}\right](3) \cdot\left(^{\wedge}\right)$ indicates resonances tentatively assigned to $\left[\mathrm{Ni}_{2}\left(\mu-\mathrm{PPh}_{2}\right)_{2}\left(\mathrm{PPh}_{3}\right)_{3}\right](4) .{ }^{11}(\$)$ indicates a resonance assignable to free $\mathrm{PPh}_{3}$. 


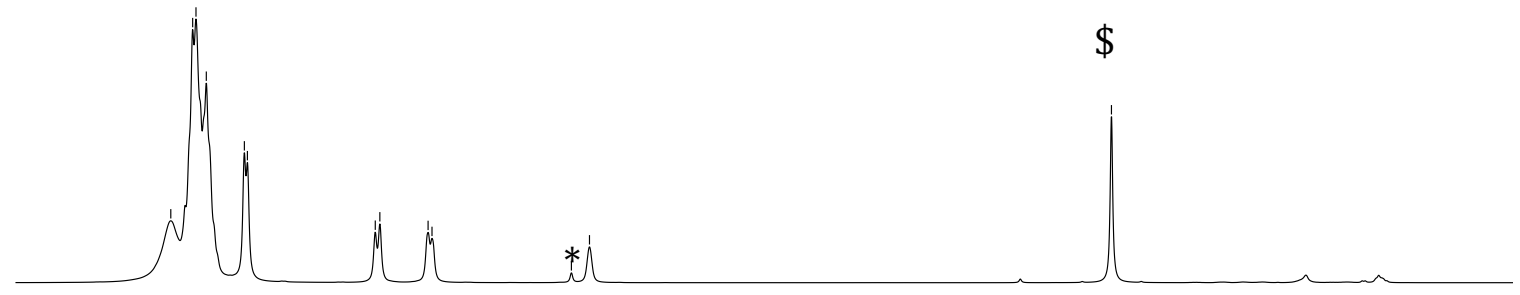

\section{$\begin{array}{lllllllllllllllll}8.0 & 7.5 & 7.0 & 6.5 & 6.0 & 5.5 & 5.0 & 4.5 & 4.0 & 3.5 & 3.0 & 2.5 & 2.0 & 1.5 & 1.0 & 0.5\end{array}$ $\delta$ (ppm)}

Figure S17. ${ }^{1} \mathrm{H}$ NMR spectrum of Gomberg's dimer in $\mathrm{CD}_{2} \mathrm{Cl}_{2}$. (\$) indicates resonances assignable to toluene. $(*)$ indicates resonances assignable to methylene chloride. 


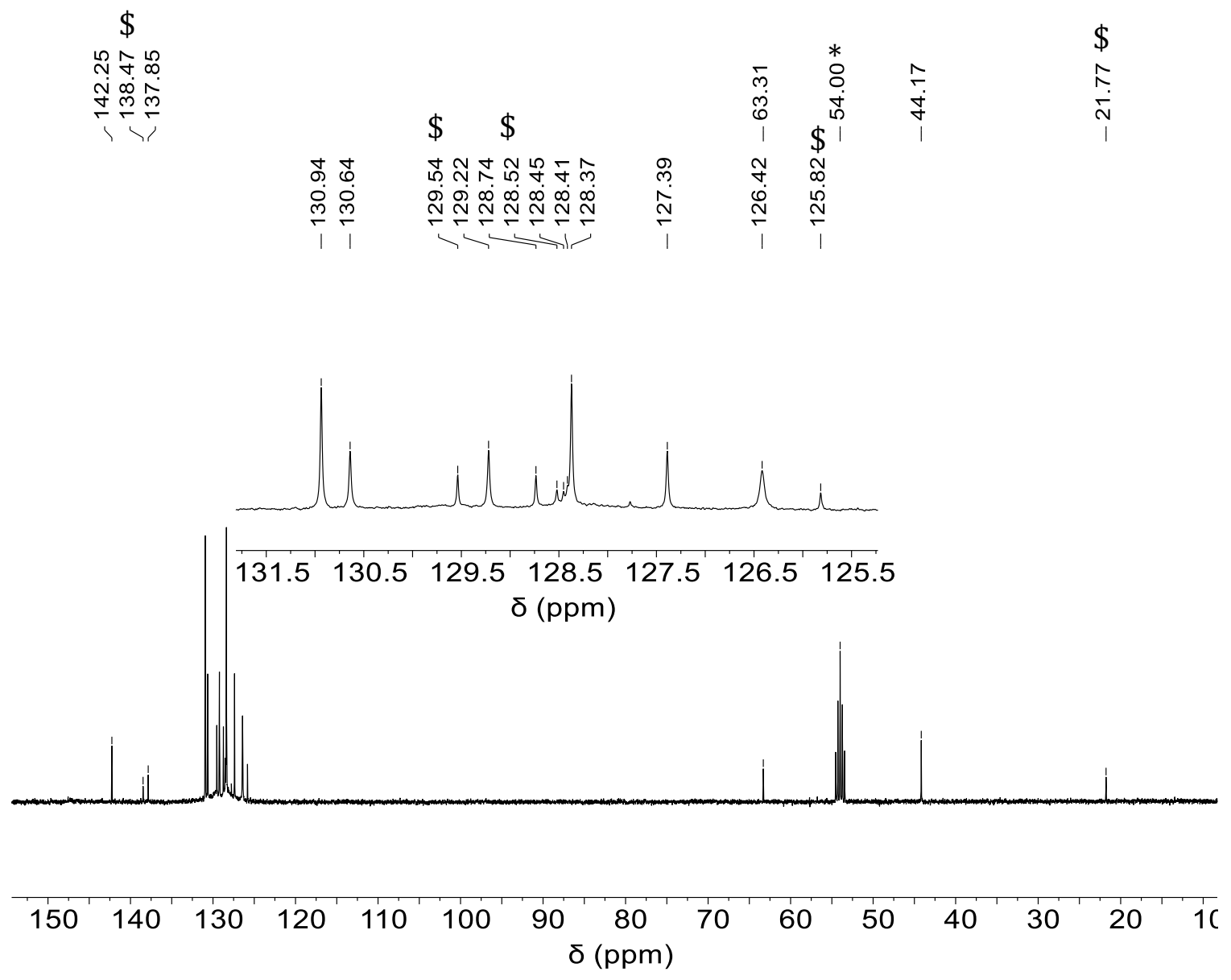

Figure S18. ${ }^{13} \mathrm{C}\left\{{ }^{1} \mathrm{H}\right\}$ NMR spectrum of Gomberg's dimer in $\mathrm{CD}_{2} \mathrm{Cl}_{2}$. (\$) indicates resonances assignable to toluene. $\left({ }^{*}\right)$ indicates resonances assignable to methylene chloride. 


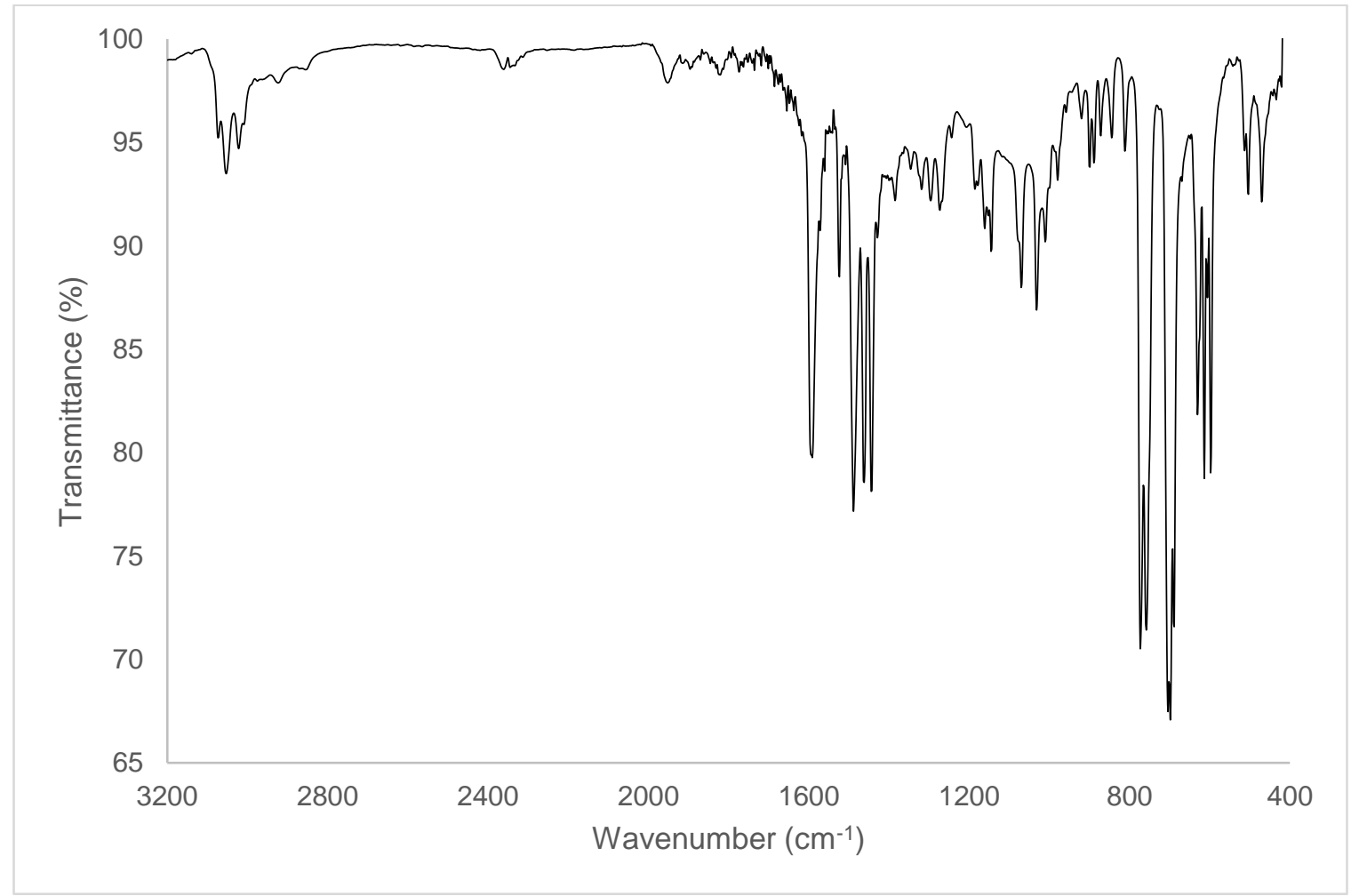

Figure S19. IR spectrum of $\mathrm{Ni}\left(\eta^{3}-\mathrm{CPh}_{3}\right)_{2}(\mathbf{1})(\mathrm{KBr}$ pellet). 


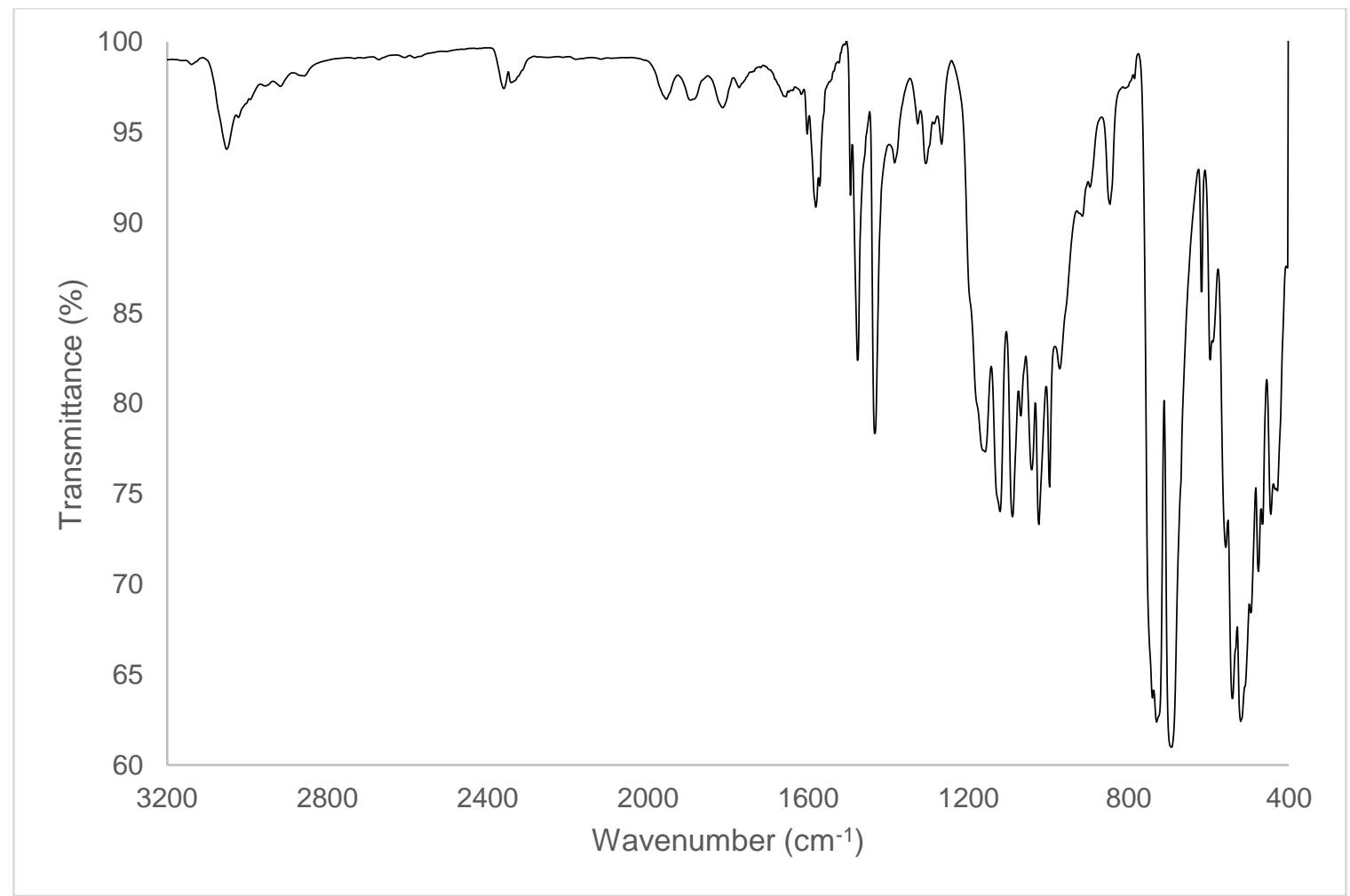

Figure S20. IR spectrum of $\left[\mathrm{Ni}_{3}\left(\mu_{3}-\mathrm{PPh}\right)\left(\mu-\mathrm{PPh}_{2}\right)_{2}\left(\mathrm{PPh}_{3}\right)_{3}\right]$ (3) (KBr pellet). 


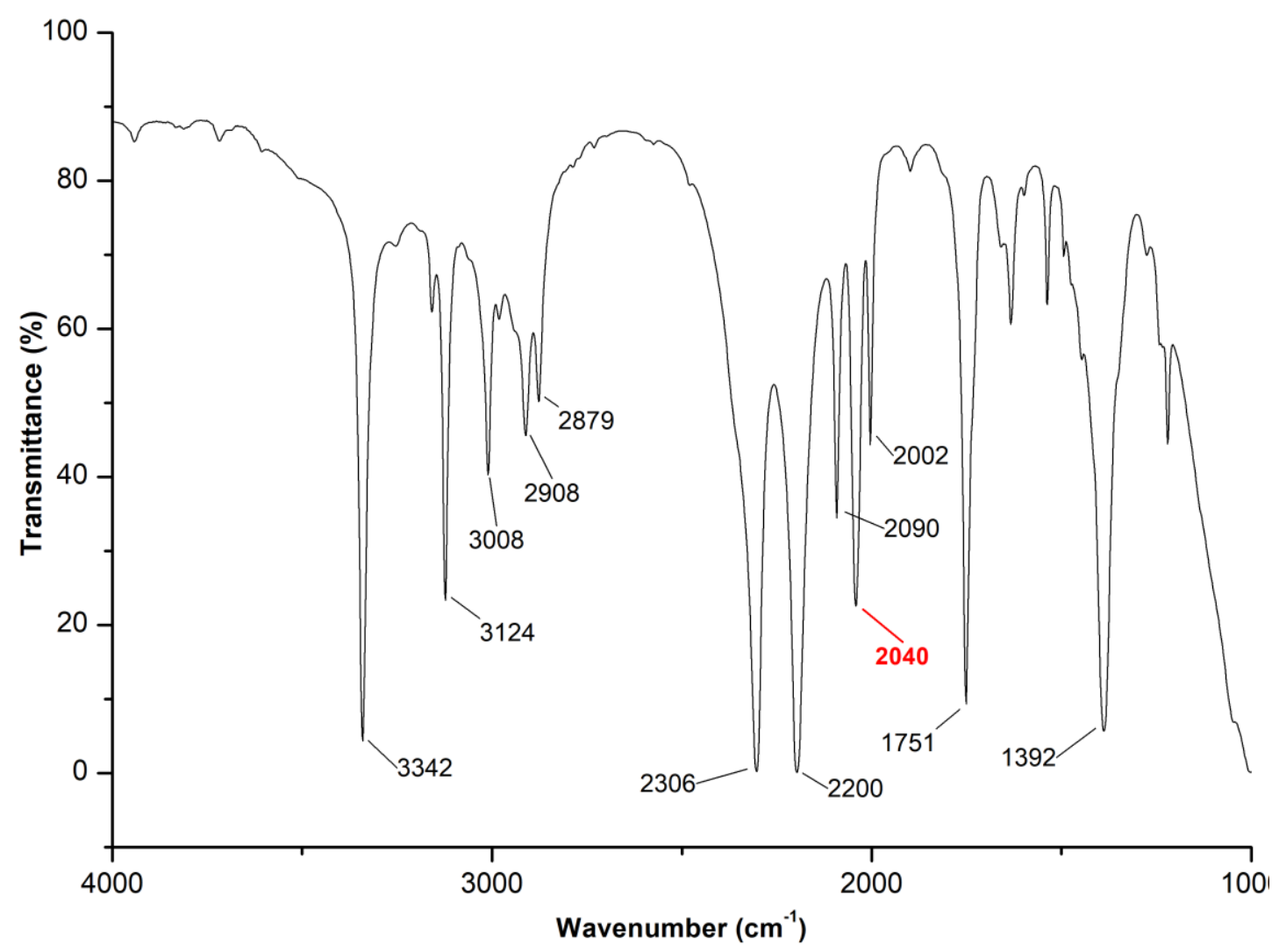

Figure S21. IR spectrum of the reaction mixture formed by reaction of $\mathbf{1}$ with excess $\mathrm{CO}$ in $\mathrm{CD}_{2} \mathrm{Cl}_{2}$. The peak at $2040 \mathrm{~cm}^{-1}$ is assignable to $\mathrm{Ni}(\mathrm{CO})_{4}$. 


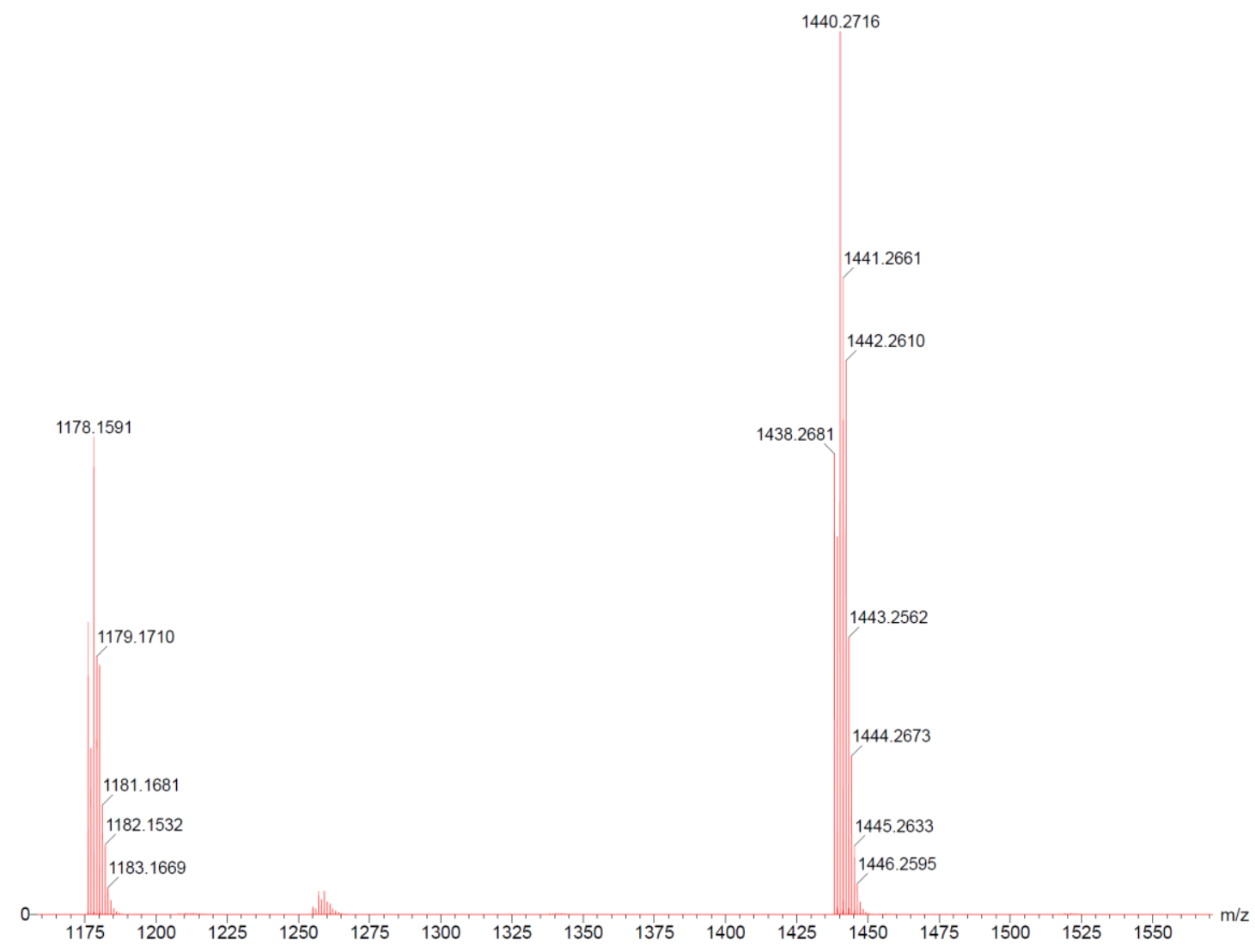

Figure S22. Partial ESI-MS (positive mode, $2 \mathrm{kV}$ ) of $\left[\mathrm{Ni}_{3}\left(\mu_{3}-\mathrm{PPh}\right)\left(\mu-\mathrm{PPh}_{2}\right)_{2}\left(\mathrm{PPh}_{3}\right)_{3}\right]$ (3) taken in THF. Peaks at $1440.2716 \mathrm{~m} / \mathrm{z}$ and $1178.1591 \mathrm{~m} / \mathrm{z}$ are assignable to [M]+ and $\left[\mathrm{M}-\mathrm{PPh}_{3}\right]^{+}$, respectively. 

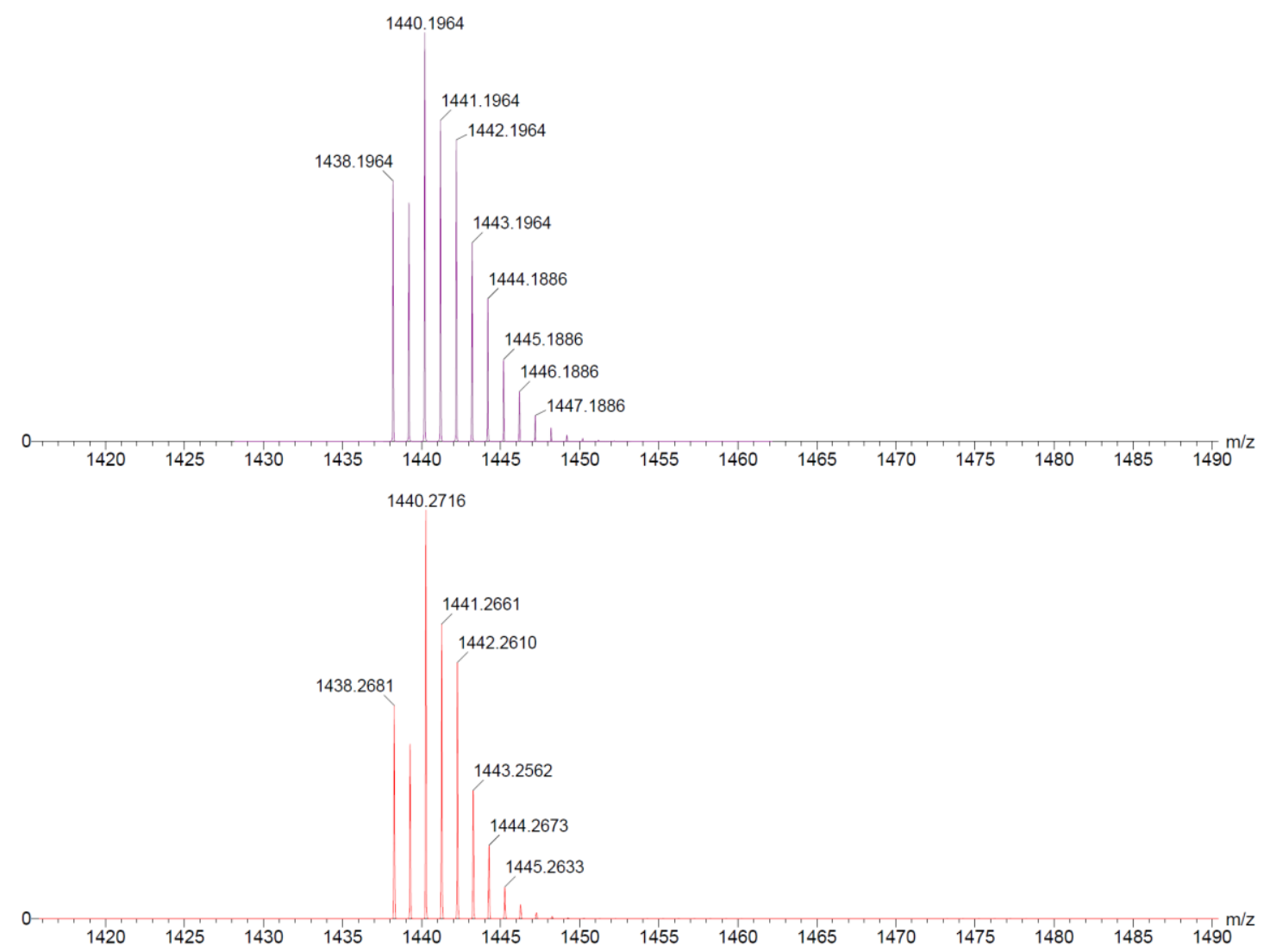

Figure S23. Partial ESI-MS (positive mode, $2 \mathrm{kV}$ ) of $\left[\mathrm{Ni}_{3}\left(\mu_{3}-\mathrm{PPh}\right)\left(\mu-\mathrm{PPh}_{2}\right)_{2}\left(\mathrm{PPh}_{3}\right)_{3}\right]$ (3) taken in THF. The experimental (bottom) and calculated (top) peaks assignable to the $[\mathrm{M}]^{+}$ion are shown. 

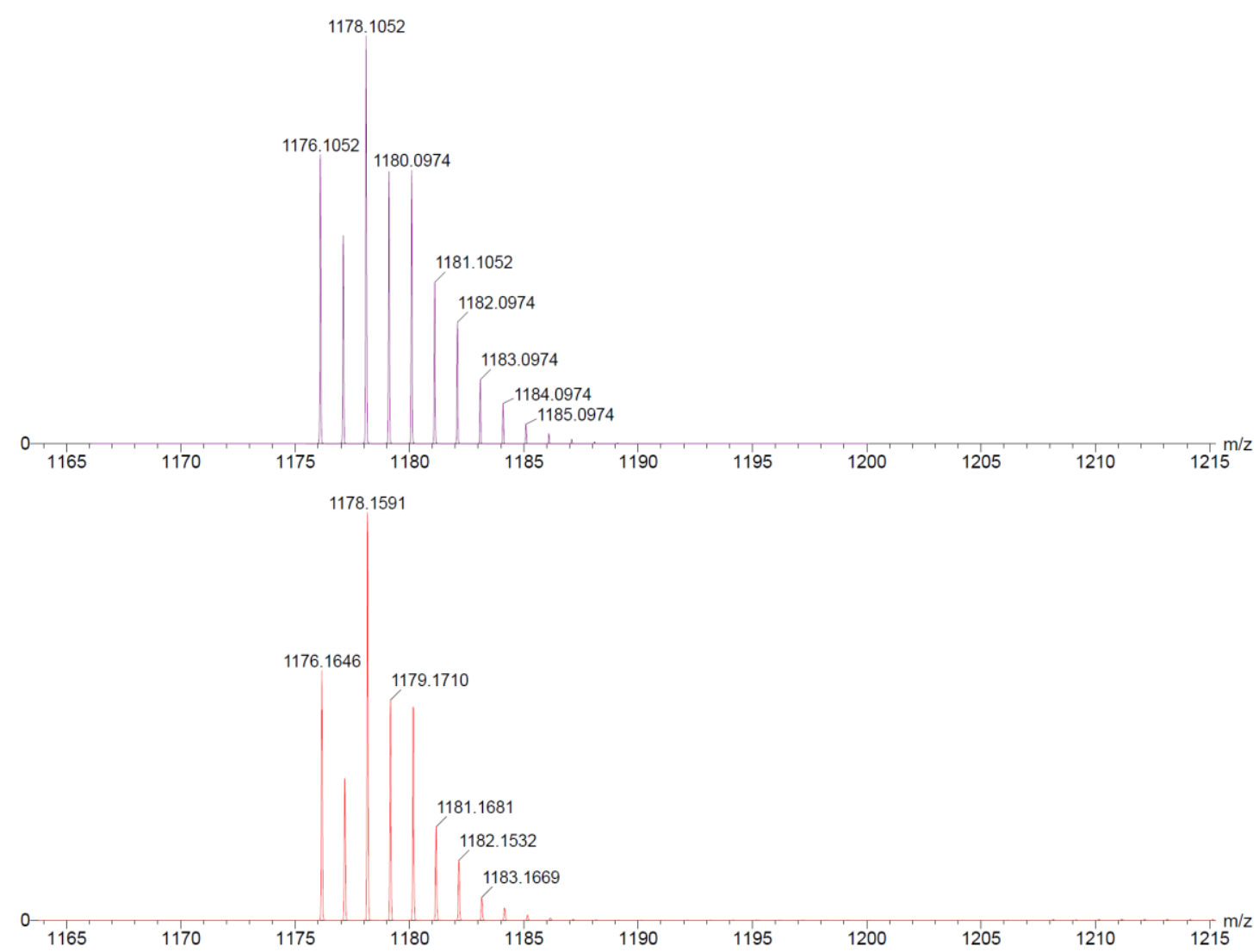

Figure S24. Partial ESI-MS (positive mode, $2 \mathrm{kV})$ of $\left[\mathrm{Ni}_{3}\left(\mu_{3}-\mathrm{PPh}\right)\left(\mu-\mathrm{PPh}_{2}\right)_{2}\left(\mathrm{PPh}_{3}\right)_{3}\right]$

(3) taken in THF. The experimental (bottom) and calculated (top) peaks assignable to the $\left[\mathrm{M}-\mathrm{PPh}_{3}\right]^{+}$ion are shown. 


\section{References:}

1. (a) Harris Robin, K.; Becker Edwin, D.; Cabral de Menezes Sonia, M.; Goodfellow, R.; Granger, P., NMR nomenclature. Nuclear spin properties and conventions for chemical shifts(IUPAC Recommendations 2001). In Pure Appl. Chem., 2001; Vol. 73, p 1795; (b) Harris Robin, K.; Becker Edwin, D.; Cabral de Menezes Sonia, M.; Granger, P.; Hoffman Roy, E.; Zilm Kurt, W., Further conventions for NMR shielding and chemical shifts (IUPAC Recommendations 2008). In Pure Appl. Chem., 2008; Vol. 80, p 59.

2. (a) Mynott, R.; Mollbach, A.; Wilke, G. In A PROOF OF THE EXISTENCE OF Ni[P(C6H5)3]4 IN SOLUTION, J. Organomet. Chem., 1980; pp 107; (b) Tolman, C. A.; Seidel, W. C.; Gerlach, D. H., Triarylphosphine and ethylene complexes of zerovalent nickel, palladium, and platinum. J. Am. Chem. Soc. 1972, 94, 2669.

3. Hartmann, N. J.; Wu, G.; Hayton, T. W., Synthesis and reactivity of a nickel(ii) thioperoxide complex: demonstration of sulfide-mediated N20 reduction. Chem. Sci. 2018, 9, 6580.

4. (a) Crawford Jr, B. L.; Cross, P. C., The vibrational spectrum and thermodynamic properties of nickel carbonyl. J. Chem. Phys 1938, 6, 525; (b) Bramley, R.; Figgis, B. N.; Nyholm, R. S., ${ }^{13} \mathrm{C}$ and ${ }^{17} \mathrm{O}$ n.m.r. spectra of metal carbonyl compounds. Transactions of the Faraday Society 1962, 58, 1893.

5. (a) Staab, H. A.; Brettschneider, H.; Brunner, H., Struktur der TriarymethylDimeren. Chem. Ber. 1970, 103, 1101; (b) Lankamp, H.; Nauta, W. T.; MacLean, C., A new interpretation of the monomer-dimer equilibrium of triphenylmethyl- and alkylsubstituted-diphenyl methyl-radicals in solution. Tetrahedron Lett. 1968, 9, 249.

6. Gomberg, M., AN INSTANCE OF TRIVALENT CARBON: TRIPHENYLMETHYL. J. Am. Chem. Soc. 1900, 22, 757.

7. SMART Apex II, Version 2.1. Bruker AXS Inc.: Madison, WI, 2005.

8. SAINT Software User's Guide, Version 7.34a. Bruker AXS Inc.: Madison, WI, 2005.

9. Sheldrick, G. M., SADABS. University of Göttingen: Göttingen, Germany, 2005.

10. SHELXTL PC, Version 6.12. Bruker AXS Inc.: Madison, WI, 2005.

11. Lu, Z.; Abbina, S.; Sabin, J. R.; Nemykin, V. N.; Du, G., Unexpected Formation of Chiral Pincer CNN Nickel Complexes with $\beta$-Diketiminato Type Ligands via $\mathrm{C}-\mathrm{H}$ Activation: Synthesis, Properties, Structures, and Computational Studies. Inorg. Chem. 2013, 52, 1454.

12. Eisch, J. J.; Yu, K.; Rheingold, A. L., 6,12-Diphenyldibenzo[b,f][1,5]diazocine as an Electron-Capture Agent: Efficient Mechanistic Probe for SET Processes and Reagent for the Oxidative Dimerization of Benzylic Organometallics. Eur. J. Org. Chem. 2012, 2012, 3165.

13. Fulmer, G. R.; Miller, A. J. M.; Sherden, N. H.; Gottlieb, H. E.; Nudelman, A.; Stoltz, B. M.; Bercaw, J. E.; Goldberg, K. I., NMR Chemical Shifts of Trace Impurities: Common Laboratory Solvents, Organics, and Gases in Deuterated Solvents Relevant to the Organometallic Chemist. Organometallics 2010, 29, 2176. 